\title{
ECONOMICS
}

\section{Political Connections and Firm Pollution Behaviour: An Empirical Study}

\author{
by \\ Yuping Deng
}

School of Economics and Trade, Hunan University, Changsha, P.R. China Yanrui Wu

Business School, The University of Western Australia

and

Helian Xu

School of Economics and Trade, Hunan University, Changsha, P.R. China 


\title{
Political Connections and Firm Pollution Behaviour: An Empirical Study
}

\author{
Yuping Deng ${ }^{\mathrm{a}, \mathrm{b}}$, Yanrui $\mathrm{Wu}^{\mathrm{b}^{*}}$, Helian $\mathrm{Xu}^{\mathrm{a}}$ \\ ${ }^{a}$ School of Economics and Trade, Hunan University, Changsha, P.R. China \\ ${ }^{\mathrm{b}}$ Economics, Business School, University of Western Australia, Perth, Australia
}

\begin{abstract}
A firm's top manager and a government official may be connected due to special circumstances. This social relationship or political connection may provide industrial polluters with protection or a "pollution shelter" which could lead to severe environmental deterioration. This paper aims to examine the link between political connections and firms' pollution discharges by using Chinese data. Empirical results show that political connections are the institutional origin for firms to adopt strategic pollution discharges. Government officials who are young, of low education, promoted locally and in office for a relatively long time are more likely to build political connections with polluters. This phenomenon may lead to inadequate enforcement of regulation and emission control. The pollution discharge of politically connected firms also varies considerably due to firm heterogeneity. This study also shows that pollution shelter effects caused by political connections are more obvious in the central and western regions, prefecture cities and capital-intensive industries.
\end{abstract}

Keywords: Political connections; pollution discharges; political promotion; China

JEL codes: Q51; L20; O12

\footnotetext{
* Corresponding author. Email address: yanrui.wu@uwa.edu.au. Work on this paper was supported by the National Natural Science Foundation of China [grant number 71703035] as well as National Social Science Foundation of China [grant number 16ZA038]. The authors gratefully acknowledge the helpful comments from anonymous referees and participants of seminars and conferences at Australasian Development Economics Workshop, University of Western Australia, Southeast University and Hefei University of Technology.
} 


\section{Introduction}

Since the launch of economic reforms and open-door policy, China has achieved phenomenal economic growth which is regarded as an unprecedented development miracle. However, the past growth model with high inputs and pollution brings about serious environmental problems such as heavy city smog, discharging of pollutants without permission and increased cases of cancer in villages. In terms of pollution control, China's political promotion system, which uses GDP growth as its core criterion, acts as a powerful factor that prompts government officials and firms' top managers to form political connections. This social relationship provides polluters with protection and indulgence (hereafter referred to by the term "pollution shelter") which may lead to severe environmental deterioration. Thus it is necessary to comprehensively evaluate firms' environmental performance from the perspective of political connections. The knowledge gained would be helpful for the construction of a resource-conserving and environmentally friendly society, as well as the reform of the government administration system in the country.

In this paper, we aim to investigate the relationship between political connections and firm pollution behaviour. Our empirical results show that political connections between local government officials and firms' top managers are the institutional origin that causes firms to adopt strategic pollution discharge, and that political connections are associated with an increase in firms' pollution discharges. Government officials with less education, a younger age, relatively longer tenure and local promotion are more likely to build political connections with polluters, which result in insufficient regulation and control for excessive emissions. Furthermore, it is shown that the pollution shelter effects caused by political connections are 
more obvious in central and western regions, prefecture cities and capital-intensive industries.

This paper contributes to the existing literature in the following three aspects. First, it broadens the definition of political connections by following a social network approach and then explores firms' strategic pollution discharge from the perspective of political connections. Political connections are defined as the links between politicians and firms' top managers in non-contractual social relations based on their birthplace. In existing studies political connections are defined as having a senior executive or board member who is a current or former government official (Faccio, 2010; Cai \& Sevilir, 2012; Ferris et al., 2016; Zheng, Singh \& Chung, 2017; Bertrand et al., 2018), having financially donated to a political party (Khwaja \& Mian, 2005; Claessens et al., 2008; Cooper et al., 2010; Titl \& Geys, 2019), or a representative in the National People’s Congress or Chinese People’s Political Consultative Conference ( Fan et al. ,2008; Cai \& Sevilir, 2012; Schweizer et al., 2017). However, this type of measurement is rough and inaccurate, especially for China (Cheng, 2018). The reason is that if the senior executives or board members worked for the government a long time ago, then their political power may disappear. Thus connections with a former official who served farther back in time have negligible effects on firm activities (Faccio, 2006). Some authors adopt the state ownership of firms as a proxy for political connections (Berkman et al., 2010; Maung et al., 2016). Since the top managers of state-owned firms maintain close ties with the government, so their motivation to build political connections is determined endogenously by the consequences of political connections (Adams et al., 2010; Do et al., 2015). In light of this we focus on political connections through the social network of birthplaces which are identified for all politicians and top managers. This network can be clearly and 
unambiguously defined by using publicly available information about the birthplaces of all politicians and top managers and is expected to strongly predict the true relationships in real life (Zhu \& Chung, 2014).

The second significant contribution is that micro-data are used to control for heterogeneity in politicians and firms, and examine the different influences of political connections on firm emission behaviour. To the best of our knowledge, several papers examined the determinants of environmental pollution at the firm level. They focused on whether exporting firms performed better environmentally than their non-exporting competitors (Cole et al., 2013; Richter \& Schiersch, 2017; Forslid et al., 2018), or tested whether foreign firms were cleaner than their domestic competitors (Earnhart \& Lizal, 2006; Wang \& Jin, 2007; Jiang et al., 2014). However, none of these studies has established a link between political connections and firms' pollution discharges. Two papers investigated the difference between politically connected firms and non-politically connected ones in environmental performance, which are most closely related to our work. The first paper by Zhang (2017) uses a panel dataset of China's listed firms to examine how political connections affect corporate environmental responsibility. In this paper political connections are defined according to whether the chief executive officer (CEO) of a list firm is a current or former official. The second paper by Maung et al. (2016) analyzes how state ownership of non-listed firms affects pollution fees. In this paper, state ownership is considered as a proxy for firms’ political connections. Their empirical results show that firms with state ownership pay lower environmental levies. In the present study, we further explore the relationship between political connections and firms’ pollution discharges. 
Third, although a growing body of literature has established a link between political connections and firm performance, it is still not very clear how political ties affect firms' pollution behavior. Some authors confirmed the success of environmental regulations in reducing pollution intensity (for example, Gray \& Shimshack, 2011; Lee et al., 2018). Others showed that environmental regulations do not reduce pollution discharges because of yardstick competition among local governments (Ogawa \& Wildasin, 2009; Bu \& Wagner, 2016). Additionally, some authors indicated that investment expansion increases the extraction of natural resources and the amount of pollutants, and hence lower environmental quality (Waldkirch \& Gopinath, 2008; He et al., 2012; Halkos \& Paizanos, 2013). Thus, we propose a mechanism-based theoretical framework to explore possible negative effects of political connections on firms' environmental performance and investigate the channels through which political connections may influence firm pollution discharges. Specifically, we find that political connections lead firms to invest excessively and hence lead to resource misallocation. Meanwhile, political connections cause the weakening of the enforcement of environmental regulations and consequently an increase in firm pollution discharges. These two mechanisms reasonably explain the phenomenon that our emission control gets more and more stringent while reduction performance is still unsatisfactory. This paper also provides theoretical support to the concept of political resource curse, which is associated with the deterioration of public policies through corruption and rent-seeking activities. Extant theoretical work on the political resource curse implies that dependence on resource revenues decreases autocracies' likelihood of democratizing. For example, Paler (2013) examined whether and why windfalls affected citizens' participation in politics, and found that 
participants were motivated to monitor and sanction the incumbent by an increase in the perceived share of taxes relative to windfalls in total revenue. Brollo et al. (2014) studied the effect of additional government revenues on political corruption and the quality of politicians. Their research showed that larger transfers increased observed corruption and reduced the average education of candidates for mayors. Chen \& Kung (2016) found the revenue windfalls accrued to these officials from land sales undermined the effectiveness of the promotion system for government officials. In this paper we attempt to richly document and test for the presence of the political resource curse by analyzing firms' environmental reactions to political connections between top managers and politicians in China.

The remainder of this paper is structured as follows. Section 2 presents the literature review and hypothesis development. Section 3 demonstrates the model specification and describes the data and choice of the variables. Section 4 presents empirical results, while Section 5 ends with conclusions and policy recommendations.

\section{Literature Review and Hypothesis Development}

\subsection{Literature Review}

Political connections include both formal and informal relationships built by local officials and firms (Bertrand et al., 2007; Faccio, 2010). Through political connections, firms have access to scarce and valuable political resources controlled by local governments (Goldman et al., 2013; Amore \& Bennedsen, 2013; Mironov \& Zhuravskaya, 2016). Research has revealed that politically connected firms significantly benefit from favorable financing (Faccio, 2010; Duchin \& Sosyura, 2012; Blau et al., 2013), tax privileges (Mobarak \& Purbasari, 2006; Kim 
\& Zhang, 2016; Chen et al., 2016), government subsidies (Faccio et al., 2006; Montmartin, 2013), and debt relief (Boubakri et al., 2008; Bliss \& Gul, 2012; Keefe, 2019). Additionally, through embedding themselves in politically connected networks, firms' top managers can win government support by participating in government decision-making (Faccio, 2006; Goldman et al., 2009), receive honours and awards (Hwang \& Kim, 2009; Polsiri \& Jiraporn, 2012; Cingano \& Pinotti, 2013), and have access to simplified approval procedures (Faccio, 2006; Wang \& Sheng, 2010). However, firms need to dedicate major resources to build and maintain political connections which undoubtedly increase their operating expenses. There are several reasons for this. First, political resources are not provided free-of-charge, but at the cost of transferring political rents to local officials (Shleifer \& Vishny, 1994; Fan et al., 2008; Amore \& Bennedsen, 2013). Second, political connections would result in the objective function of a firm being dominated by government priorities, ultimately reducing investment efficiency and triggering over-investment (Li \& Zhou, 2005; Xu et al., 2013; Schweize et al., 2017). Finally, once political connections can be transformed into competitive advantages, firms will have little incentive to improve operational efficiency and deliver cost savings (Cai \& Sevilir, 2012; Baranchuk et al., 2014).

In recent years, the analysis of government competition has been a new frontier of research on environmental issues which investigates how fiscal decentralization and political incentives affect the environment (e.g. Konisky, 2009; Millimet \& Roy, 2015). Some studies show that local government will compete for resources by lowering environmental standards in order to attract new firms and create more jobs. This "race to the bottom” in environmental regulation will lead to the deterioration of the environment (List et al., 2004; Ogawa \& 
Wildasin, 2009; Dong et al., 2015; Bu \& Wagner, 2016). Numerous studies have also shown that developed countries voluntarily lower environmental standards or relax environmental regulation in order to maintain competitiveness in pollution-intensive industries (Benarroch \& Thille, 2001; Konisky, 2007; Manderson \& Kneller, 2012; Chung, 2014). The empirical evidence from the U.S. indicates that the environmental "race to the bottom" does exist in all states (Xing \& Kolstad, 2002; Woods, 2006; Millimet \& Roy, 2015), and that environmental spillovers encourage local governments to adopt a "free-rider" approach in transboundary pollution treatment (Gray \& Shadbegian, 2004; Sigman, 2007; Sanna-Randaccio \& Sestini, 2012; Banzhaf \& Chuppd, 2012). It is also argued that Chinese decentralization, a combination of political centralization and fiscal decentralization, is the institutional background for understanding the insufficient supply of environmental public goods (Qian \& Weingast, 1996; Cai \& Treisman, 2006; Wang \& Chen, 2014). A growing body of literature reveals that fiscal decentralization and GDP growth assessment have prompted local governments to irrationally compete in the realm of environmental policies (Marquis et al., 2011; He et al., 2012). Thus, binding emission reduction targets cannot fundamentally correct the "race to the bottom" behaviour and stop the strategic endeavour of government officials (Zheng et al., 2014; Ghanem \& Zhang, 2014).

However, the existing literature mainly focuses on the costs and benefits of political connections and the effects of local government competition on the environment. It fails to analyse the role of government officials who are the decision makers. The literature also ignores how the official governance system plays a moderating role in the relationship between local government behaviour and environmental pollution. In addition, previous 
studies neglect the special circumstances of forming political connections and take insufficient account of the differences in individuals such as officials and top managers.

\subsection{Hypothesis Development}

\subsubsection{The institutional origin of strategic pollution discharge}

After nearly 40 years' endeavour, China has formed a disciplinary environmental management system featuring unified supervision and management by environmental protection departments and assignment of responsibility to local governments under the unified leadership of the central government. This management system has effectively promoted the development of environmental protection in the transition period of the economy. However, for decades, China’s economic boom has been accompanied by growing pollution and the emergence of environmental management problem. One outstanding problem is the inconsistency of environmental behaviour between central and local governments (Kostka \& Nahm, 2017). Specifically, due to fiscal decentralization, a local government actually plays the role of a double agent. On the one hand, local government, as the agent of central government, is responsible for implementing and monitoring environmental policies formulated by the central government. On the other hand, local government, as a jurisdictional agent, bears the burden of promoting the regional economy. The political promotion tournament, which mainly relies on GDP growth assessment, prompts local officials to engage in fierce competition over economic growth (Weingast, 2009; Zheng et al., 2014; vander Kamp et al., 2017). Thus, junior officials may be more likely to encourage polluting firms to operate in their jurisdictions (Borghesi et al., 2015). Meanwhile, their superiors have strong motivation to relax environmental regulations to protect their 
subordinates from being investigated and prosecuted (Kostka \& Mol, 2013). By doing so, they can minimize legal costs and realize common goals for economic growth in their jurisdictions (Yu et al., 2019).

Moreover, the environmental enforcement authority in China is affiliated with local environmental protection agencies, while the leaders of these agencies are appointed by local governments. Thus, environmental enforcement may be subjected to local government authority (Faccio, 2006; Eaton \& Kostka, 2014). This forms the basis for local government officials and firms' top managers to build political connections, for which same-hometown or birthplace identity acts as the particular node. In contrast to the cultural orientation prevalent in the West, China is a highly relationship-oriented society with a unique institutional environment that has been influenced by both its history and political ideology (Styles \& Ambler, 2003; Barnes et al., 2011; Berger et al., 2018; Guo et al., 2018). The Confucian philosophy emphasizes strong geographical relationship, which is an effective way of obtaining resources and reducing transactional costs (Hofstede, 2001; Chan \& Suen, 2005; Barnes et al., 2011). Top managers are strongly socialized groups, and their birthplaces are undoubtedly one important dimension to form personal relationships. In such a case, same birthplace identity plays a critical role in political connections (Yen \& Abosag, 2016). For an official with a well-connected family background, same birthplace identity is a beneficial channel to develop interpersonal network. For a grass-root official who has no political affiliations, same birthplace identity is the most convenient ticket to enter into the upper-class circles. Thus, once political connections are established, officials may share their political resources with their connected firms (Amore \& Bennedsen, 2013; Mironov \& Zhuravskaya, 
2016). This type of political connections provides protection for the polluters or a pollution shelter. Therefore, fiscal decentralization and political promotion tournaments imply that local government officials have strong motivation to form political connections with local firms which undermine China's environmental protection efforts. Thus, our first hypothesis is:

Hypothesis 1: Political connections between local officials and firms' top managers increase pollution discharges.

\subsubsection{Theoretical mechanism of political connections influencing the environment}

Political connections may influence the environment in two ways, namely resource misallocation and environmental regulation. As China has not yet formed a market-based resource allocation system, local governments control key resources (Feng et al., 2019). These resources could be allocated according to firms' political proximity rather than their productive efficiency (Khwaja \& Mian, 2005; Goldman et al., 2010). In this context, establishing good relationships with local governments enables firms to improve their political proximity. Local governments may give priority to politically connected firms for political purposes or personal benefits. Accordingly, politically connected firms can obtain some significant resources which affect their development and hence their production decisions. These effects may cause resource misallocation. Resource misallocation may lead firms to invest excessively and therefore generate more pollution discharges. On the one hand, politically connected firms are easier to get long-term loans from the banks and relax their financial constraints (Cull et al., 2015; Li \& Zhou, 2015). On the other hand, it is shown that political connections cause firms' goals to be dominated by government priorities and distort 
firms’ ultimate objectives. Thus, to achieve political objectives favored by local officials, firms may be forced to invest in unprofitable but politically favored projects, which results in investment inefficiency (Bliss and Gul, 2012; Boubakri et al., 2012; Piotroski \& Zhang, 2014).

In a transitional economy like China, various institutional distortions provide further opportunity for local officials to intervene in business decisions. In order to get promoted, local government officials tend to link their own political goals with investment decisions of politically connected firms through a series of preferential policies and administrative permissions (Duchin and Sosyura, 2012; Blau et al., 2013). The politically connected firms may expand their investment to maintain good relationships with local government officials and gain their support for access to key resources. To cater for local officials' interests, politically connected firms become accustomed to carrying excessive investment to boost local economic growth, which leads to overcapacity (Aggarwal et al., 2011; Duchin \& Sosyura, 2012; Cerqua \& Pelliergrini, 2014). Over-investment requires even more consumption of limited resources and hence may cause insufficient investment in environmental protection. Thus, we propose the following hypothesis:

Hypothesis 2a. Political connections cause resource misallocation that can subsequently increase firms' pollution discharges

In addition to resource misallocation, political connections may encourage local officials to relax environmental regulations and even indulge in pollution, thus deteriorating the environment. Politically connected firms may bribe local government officials so that they 
can get away with environmental regulation and penalties. In order to promote regional economy, local government officials are motivated to inadequately implement or distort environmental policies. Jia (2013) constructs a multi-task principal-agent model to analyse how promotion incentives of provincial governors affect pollution. His theoretical analysis indicates that a higher relative price of clean technologies increases the use of dirty technologies due to a substitution effect, but political connections further strengthen the substitution effect. In addition, political connections can also provide an opportunity for firms to modify or influence environmental policy and future regulations in their favor (Lyon \& Maxwell, 2008; Zhang, 2017). In other words, politically connected firms may lobby or bribe local government officials to accept lower environmental standards. Through their political connections, some firms even convey unverifiable information to decision-makers as they cannot fulfill high environmental standards and force governments to relax the standards. In this case, relaxed environmental regulations lower the barrier to entry for heavy polluters and reduce the willingness for emission reductions which harm sustainable development. Therefore, the following hypothesis is formulated:

Hypothesis 2b: Political connections weaken the enforcement of environmental regulations and consequently increase firms'pollution discharges.

\subsubsection{The effects of politicians’ personal characteristics}

The enthusiasm of local politicians towards GDP growth and other development goals will be affected by their own personal characteristics (Li \& Zhou, 2005). The existing literature indicates that politicians' person characteristics significantly influence their 
probability of promotion (Persson \& Zhuravskaya, 2012; Jia, Kudamatsu \& Seim, 2015). Age is a critical factor determining turnover (Bach \& Veit, 2018). In particular due to age limits for promotion, ambitious officials are compelled to seek promotion as early as possible to avoid premature and permanent career stagnation (Kou \& Tsai, 2015). China’s GDP-led promotion system may drive officials to turn a blind eye to environmental standards and pollution discharges. According to China's Civil Service Retirement System, the age for promotion opportunity is capped at 55 for prefecture officials and 60 for municipal officials. Young officials have stronger promotion desire (Fan et al., 2008; Yu et al., 2019). They may use their administrative power to induce big investment from local firms to boost short-term growth (Rawski, 2002; Firth et al., 2012). Thus, younger officials are more likely to build political connections with local firms which result in more pollution discharges. Relatively elder officials have less chance for promotions and are probably more concerned with their reputations. They may endeavour to balance economic growth with environmental protection (Li \& Zhou, 2005). Therefore, the following hypothesis is proposed:

Hypothesis 3a: Young officials are more likely to build political connections with polluters, which result in excessive emissions.

Educational background may also influence officials’ attitude towards environmental protection. Local officials with higher education are less likely to build political connections with polluting firms for two reasons. On the one hand, the probability of promotion for local officials increases with their education qualifications (Glaeser \& Saks, 2006). In order to reduce the opportunity costs from administrative punishment, highly-educated officials are 
less willing to provide pollution shelter to politically connected firms. On the other hand, officials with higher educational background may have better professional skills and knowledge which help them pay more attention to environmental quality than less-educated officials (Yu et al., 2019). Thus, we propose the following hypothesis:

Hypothesis 3b: Less-educated officials are more likely to build political connections with polluters and thus result in an increase in pollution.

Relevant literature indicates that local officials' tenure may influence firms' pollution discharges in two ways. On the one hand, shorter tenure reduces the possibility of political connections between local officials and polluters as this relationship requires a certain time to build and is not provided free-of-charge (Shleifer \& Vishny, 1994; Fan et al., 2008). However, longer tenure may lead to new interest-led networks between local officials and polluters (Fredriksson \& Svensson, 2003). On the other hand, as prefectural officials serve no more than two consecutive terms in the same position, or ten years in total, so they face increased pressure to be promoted ( $\mathrm{Li} \&$ Zhou, 2005; Yu, et al., 2019). Thus, local officials will be inclined to disregard environmental pollution control and pursue more outstanding economic performance. An excessive focus on economic performance contributes to environmental degradation as local officials may acquiesce to or even indulge firms in permitting their pollution discharges (Jia, 2017). Therefore, we have the following testable proposition.

Hypothesis 3c: Longer tenure helps establish political connections which provide protection for polluting firms and result in more pollution discharges. 
Different types of appointment may also affect firms’ pollution discharges. Being subjected to existing interpersonal connects and executive power, officials promoted locally are hard to carry out stringent environmental regulations on local heavy polluters. Persson \& Zhuravskaya (2012) further pointed out that officials promoted locally were inclined to build political connections with polluting firms and relax environmental regulations because their firms were large taxpayers. Thus, officials promoted locally are more likely to get support from local elites and form alliances with them, and establish political connections with polluting firms (Li \& Zhou, 2005). Compared with local promotion, external appointments can break the well-connected networks between ex-officials and local firms and enhance the effectiveness of environmental regulations, thereby curbing polluting activities to some extent. Parallel move may reduce the possibility of political connection because the parallel-moved officials need to spend more time to establish new connections with local firms (Kanbur \& Zhang, 2009). Thus, our testable hypothesis is the followings.

Hypothesis 3d: The negative effect of political connections on firms'pollution discharges is more profound if officials are promoted locally.

With the adjustment of the system assessing officials as well as further development of the anti-corruption campaign after the $18^{\text {th }}$ National Congress of the Communist Party of China, the costs of political connections sharply increased (Fan et al., 2008; Vadlamannati, 2015). On the one hand, it is now more difficult for local officials to get private benefits by providing pollution shelter to politically connected firms. On the other hand, the anti-corruption measures have made it difficult for local firms to obtain protection. Therefore, 
increased costs for political connections inevitably result in remarkable changes in pollution discharges. In addition, many corrupt officials are caught during the anti-corruption campaign which inevitably influences the duration of political connections (Boly \& Gillanders, 2018). Although political connections help firms to look for pollution shelter by rent-seeking activities, they exist in a grey area between legal and illegal system. Once local officials are caught because of corruption, political connections will be broken. Thus, the anti-corruption campaign increases the risk of rupture in political connections and reduces firms' pollution discharges. Thus, we propose the following testable hypothesis:

Hypothesis 3e: The negative effect of political connections on firms' pollution discharges declines during the anti-corruption campaign

\subsubsection{The effects of firm heterogeneity}

The market plays an important role in optimizing the resource allocation (Hsieh \& Klenow, 2009; Matvos \& Seru, 2014). China’s economic development strategy gave priority to support economic growth in eastern regions before 1999 and then emphasized regional coordinated development. Thus, there is a big gap in the degree of marketization among eastern, central and western regions (Yu et al, 2019). Over the past four decades, eastern regions have gained larger institutional dividend due to market-oriented reforms. Although central government implemented the western development strategy in 1999 and the central rising policy in 2005 to narrow regional differences, the degree of marketization in eastern regions is still higher than other regions. Therefore, owing to different marketization degree, the effect of political connections on the environment in different regions varies. Subnational 
regions with a lower degree of marketization face uncertainties in eco-innovation processes due to informational asymmetries and weaker intellectual property protection (Barbosa \& Faria, 2011; Tebaldi \& Elmslie, 2013). Thus, firms located in these regions are less motivated to conduct eco-friendly innovations. Instead they may seek pollution shelters. In contrast, subnational regions with a higher degree of marketization have distinct advantages in information collection and property rights protection. Firms located in these regions are more motivated to conduct green innovation in order to obtain or keep competitive advantages. In addition, the legal environment is weaker in central and western regions, and governments are less active in pollution abatement and regulations. Some local officials are even politically connected with polluters for their personal interests, resulting in no penalties or less stringent penalties for excessive pollution discharges. Lastly, weaker legal environment creates a fertile ground for corruption (Albert \& Wouter, 2011; Badinger \& Nindl, 2014). In order to control compliance costs, firms often ignore investment or innovation in pollution abatement and discharge pollutants excessively. Their behavior may be tolerated by local governments due to political connections (Fredriksson \& Svensson, 2003). These discussions lead to the following hypothesis:

Hypothesis 4a: The negative effect of political connections on the environment is more profound if firms are located in central and western regions.

There are three different administrative levels of cities in the Chinese urban system: municipalities, provincial capital cities and prefecture-level cities. Different administrative levels of cities have obvious differences in their capacities in obtaining financial resources 
(Henderson \& Ge, 2005). Municipalities are the highest level of cities that are directly controlled by the Chinese government, with status equal to that of the provinces. Provincial capital cities are the administrative centers of corresponding provinces, with status higher than prefecture-level cities. In this political system, the financial resources mainly include financial support and preferential policies (Parks et al., 1996). Higher administrative levels of cities have more preferential policies and financial support from central government, which remarkably reduce firms’ production costs and improve their investment in green innovation. The role of central government in environmental regulations is in diametrical opposition to the role of local governments (Konisky, 2009; Millimet \& Roy, 2015). The central government expects that firms can abide by environmental standards and control their pollution discharges. However, local governments tend to sacrifice the environment in exchange for rapid economic growth. Especially prefecture-level cities are lightly regulated by central governments, so they have more administration discretion in regulating local polluting firms. Thus, local officials in prefecture-level cities are much easier to build political connections with polluters which result in excessive pollution discharges. We hence propose the following hypothesis:

Hypothesis 4b: The negative effect of political connections on the environment is more profound if firms are located in prefecture-level cities.

The effects of political connections on firms' pollution discharges vary across different industries. Firms in capital-intensive industries which are often pollution-intensive ones benefit more from rent-seeking activities and are more motivated to look for pollution shelters 
via political connections (Elliott \& Shimamoto, 2008). Additionally, developing labor-intensive industries has become a preferred selection for local governments due to their strong capacities to create jobs. A large number of labor-intensive enterprises characterized by high-energy consumption and low-tech implementation are supported by local governments and create serious environmental problems. In contrast, political connections help technology-intensive enterprises obtain $R \& D$ subsides and preferential policies from the governments. These benefits not only can effectively increase $R \& D$ investment of politically connected enterprises but also reduce innovation risks (Boubakri et al., 2008; Sena et al, 2018). Politically connected, technology-intensive enterprises can adopt clean production technologies to improve their energy efficiency and pollution treatment, so their pollution discharges may be lower than those by capital intensive and labor-intensive ones. Therefore, this study proposes the following additional hypotheses:

Hypothesis 4c: Political connections have the strongest negative effect on firms' pollution discharges in capital-intensive industries, followed in turn by labor-intensive industries and technology-intensive ones.

\section{Research Design}

\subsection{Empirical Specifications}

The main econometric specification in this study is related to Zhang. (2017), who used chief executive officer who is a current or former government bureaucrat to define a firm's political connection and examined its relationship with corporate environmental responsibility. 
To test Hypothesis 1, the following panel data model is considered:

$$
\text { Pollution }_{i t}=\alpha_{0}+\alpha_{1} \text { Political }_{i t}+\sum \beta_{k} \text { Control }_{i t}+\beta_{t} \text { Year }_{\mathrm{t}}+\beta_{j} \text { City }_{+} \beta_{m} \text { Industry }_{m}+\varepsilon_{i t}
$$

where the subscripts denote firm $i$, city $j$, industry $m$, control variable $k$ and year $t$. Pollution is an indicator of environmental pollution, Political is the index of political connections, and Control denotes control variables that affect pollution. The dummy variables of year, city and industry are also included to control for unobserved fixed effects that are correlated with the main regressors, and $\varepsilon$ is the residual term.

To test Hypothesis 2, model (1) is extended as follows

$$
\begin{aligned}
\text { Pollution }_{i t}= & \alpha_{0}+\alpha_{1} \text { Political }_{i t}+\alpha_{2} Z_{i t}+\alpha_{3} \text { Political }_{i t} \times Z_{i t}+\sum \beta_{k} \text { Control }_{i t} \\
& +\beta_{t} \text { Year }_{\mathrm{t}}+\beta_{j} \text { City }+\beta_{m} \text { Industry }_{m}+\varepsilon_{i t}
\end{aligned}
$$

where $Z$ denotes the channel through which political connections influence the environment. These channels in turn include resource misallocation (Misallocation) and environmental regulation (Regulation).

\subsection{Data Sources}

For this study, we matched the hometown information of 643 mayors during the period of 2007-2015 with the unbalanced panel data of the listed firms in China. Data are drawn from several sources. First, the database of the Institute of Public and Environmental Affairs (IPEA) provides information about environmental records of about 300,000 firms during 2004-2016. This database discloses firms' pollution information provided by the Ministry of Environment Protection (MEP) for 338 prefecture-level cities and counties. In practice, firms 
are required to self-report their emissions and then inspected by the MEP each year. Each firm files an emission form to provide its pollution discharges. After monitoring and inspecting by MEP, the form will be then uploaded in the website of IPEA. The emission form is very detailed and consists of six sets of questions: (1) basic information about firm address, industry category, main products, main types of pollution and discharge standards; (2) the volume of water used for production and volume of waste water discharge (including chemical oxygen demand, ammonia nitrogen and suspended solids); (3) the volume of gas discharge (including sulfur dioxide, nitrogen oxide, industrial dust and soot); (4) carbon dioxide emissions and energy consumption (including soft coal, diesel, natural gas, power consumption, etc.); (5) the volume of general industry solid waste and hazardous waste; (6) supplementary information (including original monitoring report and confirmation letter).

Since the pollution information provided by IPEA needs to be manually collected, it has not been widely used in the existing literature. To the best of our knowledge, Tarantino \& Zimmermann (2017) explored the technical decisions shaping an official pollution information database built by IPEA and discussed the issues of standardization, power distribution and institutional fragmentation. Eaton \& Kostka (2017) examined the so-called “central state-owned enterprise problem” in China’s environmental governance system. The majority of their cited cases comes from the IPEA corporate environmental performance web portal. Shen et al. (2017) collected the information of environmental violation records with the help of Python software to examine whether environmental regulation caused pollution to be relocated nearby. Jiang et al. (2018) used the data of the pollution information transparency 
index collected by IPEA and examined the relationship between environmental policy and firms’ innovation performance.

Second, the China Stock Market Accounting Research (CSMAR) database contains information on corporate top managers such as birthplace, age, educational background, work experience, sector and ownership of listed companies, and other financial indicators. Hereby, top managers reported in the CSMAR database consist of board members and senior executives. The former includes executive directors and independent directors. The executive directors include executive officers, large shareholders and representatives of other stakeholders such as labor unions, board of supervisors, and so on. The senior executives include general managers or presidents, vice general managers or vice presidents, chief financial officers or financial managers, legal representatives, and so on. According to the names and registered addresses of listed firms, the IPEA and CSMAR databases are matched.

Third, the biographical information about politicians is mainly sourced from several websites such as people.com, xinhuanet.com and Baidu Encyclopedia. These sites have information about politicians' birthplace, age, educational background, work experience, tenure and professional qualifications.

Finally, city data are collected from the China Economic Information Network Statistics Database, which includes the names of the cities in each province, their GDP per capita, fiscal revenues and expenditures.

The raw data were filtered according to several criteria. First, observations with negative 
pollution volumes or without any pollution information were deleted. Second, observations were deleted if the net value of fixed assets and total assets is either negative or zero or if the net value of fixed assets is larger than total assets. Third, the listed companies without their top managers' biographical information are excluded. Finally, the observations have at least two years of data available in the database. After cleaning, the final sample comprises 3,988 firms with 15,238 firm-year observations covering the years of 2007 to 2015. Capital variables are deflated by using the price index of investment in fixed assets with a base year of 2000, and GDP per capita are deflated by using GDP price index

\subsection{Variable Definitions}

The dependent variable is environmental pollution (Pollution). In the literature, pollutant intensity and pollutant emissions are widely used to measure environmental pollution. Pollutant emissions reflect the total amounts of discharge as a result of economic activities, while pollutant intensity reflects emissions relative to economic activities. In this paper we mainly focus on sulfur dioxide intensity (SO2 for short) as a measure of environmental pollution. The intensity of industrial SO2 emissions defined as SO2 emissions over the value of sales. There are several reasons. First, SO2 is considered the most threatening environmental pollution generated by China's manufacturing sector, and it has been widely used as a major indicator to measure environmental pollution (He et al, 2012; Jiang et al., 2014; Zeng et al., 2018). China’s energy consumption structure determines that SO2 becomes the chief constituent of coal-related pollution. At present, China is the world's largest producer and consumer of coal, and hence the world's biggest emitter of SO2. About $90 \%$ of 
SO2 emissions come from coal burning. Second, SO2 is the main cause of acid rain and sulfuric fog, and therefore harmful to human health. Thus, SO2 emission is strictly monitored by national governments. In 1998, the State Council of China initially set up two control zones to implement tougher regulatory policies in order to reduce SO2 emission. Subsequently, during the eleventh five-year plan period (2006-2010), SO2 was specified as a major pollutant for targeted reduction. Finally, the information for SO2 provided by IPEA is much more complete than that for other pollutant types in the dataset, and can effectively ensure data consistency and hence may help obtain better results.

The main independent variable is political connections (Political). The existing literature uses a proxy variable to measure political connections in the form of the political background of firms' top managers or personal relationships (Bertrand et al., 2007; Faccio, 2010; Cai \& Sevilir, 2012). In China, personal connection between individuals with the same hometowns or birth places can often be established easily. In this paper, it is thus defined that, if the local official has the same birthplace as one of the top managers of a listed firm located in the official's jurisdiction, then the political connection variable takes the value of one and zero otherwise. The underlying assumption is that the official and top manager are connected due to being born in the same place.

During data processing, it was found that some top managers and officials only provided their birthplaces at the prefecture level. The registered address of a firm is also detailed at the prefecture level. In the Chinese administration system, at the prefecture level, the secretary of the Communist Party is mainly responsible for party organizations and performance 
management, and the mayor runs the daily management of the economy. In view of this arrangement, we focus on the political connections between the city mayor and the top manager of the firms located in that city. For robustness checks, we also consider two optional definitions of political connections. First, we use the birthplace information at the provincial level to define political connections. Thus, Political_province takes the value of one if the local official shares the same birthplace as the top manager at the provincial level and zero otherwise. Second, we define political connections on the basis of whether a company's top manager and the mayor graduated from the same university. That is, if one of the top managers of a listed firm graduated from the same university as the mayor in whose district the company is located, then political connection variable Political_school takes the value of one, and zero otherwise.

To minimize estimation biases due to omitted variables, we add some firm-specific control variables that may affect pollution. These control variables are illustrated as follows.

Liability ratio (Liability). A high liability ratio significantly reduces the capacity of firms to repay their debts and leads to insufficient funding to fulfil environmental responsibility. We use the ratio of total debts over total assets as a measure of liability ratio.

Profitability is another factor influencing polluters’ performance. Generally speaking, with better profitability, firms are inclined to spend more on the environmentally friendly facilities and technologies and eventually reduce their pollution discharge. In this paper, profitability is measured by the ratio of net profits over net assets. 
Firm scale (Scale) also affects emission efficiency. A large company may pay greater attention to its social image and long-term development, and hence undertakes more initiatives to fulfil its environmental responsibility. However, the expansion of scale may lead to a larger demand for energy and resources. The firm scale is measured by the natural logarithm of total assets.

Property rights (Ownership). State-owned enterprises (SOEs) keep close contact with local governments and have great bargaining power in negotiating pollution discharges (Wang \& Jin, 2007; Maung et al., 2016). Thus, property rights may have a profound influence on the environment. Following Kato \& Long (2006), Donelli et al. (2013) and Su et al. (2018), we divide the firms into SOEs and non-SOEs according to their ultimate controllers. SOEs are usually defined as firms whose ultimate controllers are the state while non-SOEs are defined as firms whose ultimate controllers are others. The dummy variable Ownership takes the value of one for SOEs and zero for non-SOEs.

In line with Cole et al. (2013) and Jiang et al. (2014), we use population density (Population), per capital income (Pgdp) and industrial structure (Manufacturing) to control for city-level characteristics.

Population is measured by the number of people per unit area. High population density will produce more pollution on the one hand and lead more people to participate in environmental protection on the other hand.

GDP per capita (Pgdp) is an important variable that affect environmental pollution. The relationship between GDP per capita and environmental pollution may show a inverse 
U-shape (Grosman \& Krueger, 1995), so we use quadratic forms to describe the impact of output per capita on environmental pollution.

Industrial structure (Manufacturing) is measured by the ratio of industrial added value in manufacturing to GDP. Quickening industrialization leads to the unrestrained exploitation of natural resources and a sharp increase in emissions discharges at the early stage of economic growth. However, when economic growth transforms gradually from extensive-scale expansion to intensive growth, the industrial structure will be upgraded and the environmental quality will be improved.

We also investigate the precise channels through which political connections affect firms' pollution discharges. More specifically, our theoretical framework shows that political connections may lead to resource misallocation and unfair implementation of environmental regulation, which would in turn increase firms' pollution discharges. Thus, the two channels can be defined as follows.

Resource misallocation (Misallocation). Resource misallocation is mainly reflected through investment expansion. The scale and technological effects brought by investment expansion can improve energy efficiency and carbon-reduction technology. However, excessive investment expansion will inevitably increase the demand for energy and resources. The growth rate of net fixed assets is used to measure the effects of investment expansions.

Environmental regulation (Regulation). Pollution treatment expenditure as well as inspection times for pollution discharges are used to measure environmental regulation in the literature (Lanoie et al., 2008; Cole et al., 2010; Kneller \& Manderson, 2012; Brunel \& 
Levinson, 2016). However micro-level data for Chinese firms are either unavailable or incomplete. For this reason, the removal ratio of industrial sulphur dioxide (the ratio of the removal amount of industrial sulphur dioxide to total amount of flue gas discharged) is used as a measure of environmental regulation following Freeman \& Kolstad (2006) and Chio et al. (2018). Therefore, the higher this ratio, the stricter the environmental regulation and control is.

All variables are as defined in the Appendix A. Table 1 presents the summary statistics of the variables used in the main analyses. Panel A reports summary statistics for major variables discussed in Section 3. There are large variations in SO2 intensity across the sample, indicating that there are significant differences between firms' pollution discharges. Among the 15,238 firm-year observations, $2.66 \%$ of local officials share the same city birthplace as one of the top managers of the listed firms located in the officials' jurisdiction, while $2.81 \%$ local officials share the same provincial birthplace as the top managers of the listed firms. In contrast, only $2.21 \%$ top managers graduated from the same university as the mayors of the districts where the firms are located. The statistics of control variables show that firms are highly levered, with an average asset-to-liability ratio of $4.53 \%$. The average profitability is $43.07 \%$, with a standard deviation of $23.31 \%$. In addition, there is significant difference in firms' scale. It can be found the natural logarithm of total assets in the largest firm is 28.5510 , which is about 4.24 times than that in the smallest firm. $28.43 \%$ of the sample firms are SOEs, and the remaining $71.57 \%$ are non-SOEs. Panel A also shows that the average population density is 579.71 persons per square kilometer in each city. The average ratio of industrial added value in manufacturing to GDP is 0.51 , with a standard deviation of $19.87 \%$. 
Panel B compares the average pollution intensity of firms with political connections with that of firms without political connections. It can be found that the average pollution intensity of politically connected firms is much higher than that of firms with no political connection. Thus, the univariate analysis demonstrates that political connections are positively associated with firms’ pollution intensity.

Table 1 Descriptive Statistics of the Variables

\begin{tabular}{|c|c|c|c|c|c|}
\hline \multicolumn{6}{|c|}{ Panel A: Descriptive Statistics for the Major Variables } \\
\hline Variables & Observations & Mean & Std. Deviation & Minimum & Maximum \\
\hline $\mathrm{SO} 2$ & 15,238 & 0.4618 & 2.0143 & 0.0050 & 14.9859 \\
\hline Political & 15,238 & 0.0266 & 0.1608 & 0 & 1 \\
\hline Political_province & 15,238 & 0.0281 & 0.1652 & 0 & 1 \\
\hline Political_school & 15,238 & 0.0221 & 0.1471 & 0 & 1 \\
\hline Liability & 15,238 & 0.0453 & 0.1634 & $4.22 \mathrm{e}-5$ & 2.6676 \\
\hline Profitability & 15,238 & 0.4307 & 0.2331 & $3.56 e-5$ & 1.4227 \\
\hline Scale & 15,238 & 22.5217 & 1.6958 & 6.7218 & 28.5510 \\
\hline Ownership & 15,238 & 0.2843 & 0.4511 & 0 & 1 \\
\hline Population & 15,238 & 579.7063 & 403.3573 & 16.1664 & 2648.2560 \\
\hline Pgdp & 15,238 & 1.6061 & 1.0871 & 0.1869 & 13.3341 \\
\hline Manufacturing & 15,238 & 0.5126 & 0.1987 & 0.1974 & 0.8508 \\
\hline Misallocation & 15,238 & 0.1233 & 0.1897 & 0 & 0.8066 \\
\hline Regulation & 15,238 & 0.4943 & 0.2437 & 0.0138 & 0.6990 \\
\hline \multicolumn{6}{|c|}{ Panel B: Univariate Analysis } \\
\hline \multicolumn{2}{|c|}{ Political Connections } & Observations & Mean & Differences & T-statistic \\
\hline \multicolumn{2}{|c|}{ Political $=0$} & 14,832 & 0.5488 & \multirow{2}{*}{$-0.4880 * * *$} & \multirow{2}{*}{-4.8133} \\
\hline \multicolumn{2}{|c|}{ Political $=1$} & 406 & 1.0368 & & \\
\hline \multicolumn{2}{|c|}{ Political_province $=0$} & 14,811 & 0.5483 & \multirow{2}{*}{$-0.4786 * * *$} & \multirow{2}{*}{-4.8387} \\
\hline \multicolumn{2}{|c|}{ Political_province $=1$} & 427 & 1.0271 & & \\
\hline \multirow{2}{*}{\multicolumn{2}{|c|}{$\begin{array}{l}\text { Political_school }=0 \\
\text { Political_school }=1\end{array}$}} & 14,893 & 0.3683 & \multirow{2}{*}{$-0.1999 *$} & \multirow{2}{*}{-1.7954} \\
\hline & & 345 & 0.5682 & & \\
\hline
\end{tabular}

Note: ${ }^{*}, * *$ and $* * *$ indicate significance at the $10 \%, 5 \%$ and $1 \%$ levels, respectively. 


\section{Empirical Results}

\subsection{Baseline Estimates}

For most observations in this study, the main explanatory variable Political is less time-varying. In such case, if the dummies for firms are included in the regression models and the within estimator is employed, the fixed-effect models cannot compute coefficients for time-invariant variables and result in inefficiency in estimating the effect of variable (Baltagi, 2001; Hsiao, 2003; Wooldridge, 2010). Inefficient estimates not only lead to somewhat higher standard errors but also highly unreliable point estimates and may thus cause wrong inferences in the same way as a biased estimator could (Wooldridge, 2010). Therefore, the inefficiency of the fixed-effect models in estimating time-invariant variables needs to be taken seriously. In light of this most applied researchers apparently estimated empirical models that include less time-invariant variables by pooled OLS (see for example, Huber \& Stephens, 2001; Acemoglu et al., 2003; Heineck \& Anger, 2010; Yang, 2011; Boubakri et al., 2012; Jiang et al., 2014). Thus, we employ a pooled ordinary least squares (POLS) model to estimate the effects of political connections on firm’s pollution intensity.

Table 2, Column (1) presents our estimation results based on Equation (1). The estimated results show that the coefficient of Political is 0.3174 and significant at the $5 \%$ levels, indicating that the pollution discharges by politically connected firms are 0.3174 higher than those by firms without political connection. Thus, we can draw the conclusion that political connections are negatively linked with firms' SO2 reduction and hence Hypothesis 1 is confirmed. One possible explanation is that local officials associated with polluters fail to implement or may even distort the environmental policies in order to unduly pursue GDP 
growth. Another reason is that favourable policies, such as state bank credit and land usage rights, provided for politically connected firms may discourage these firms from adopting advanced technologies which would reduce emissions.

The results in Column (1), Table 2 also demonstrate that the coefficient of Liability is negative but fails to pass the significance test at the $10 \%$ level, indicating that a rise in liability has no significant effect on firms’ pollution discharges. However, firm profitability has a significant and negative influence on pollution discharge, and an increase in firm profitability will decrease its pollution intensity by 0.3812 . The coefficients of Scale are negative and significant at the 5\% levels, implying that firms can obtain positive externalities from economies of scale and reduce their pollution discharges. Additionally, the results show that the coefficients of Ownership are negative but fail to pass the $10 \%$ significance test, which implies that there is no significant difference in pollution intensity between SOEs and non-SOEs. The reason might be that, although SOEs keep close contact with local governments and have great bargaining power with local environmental authorities to negotiate environmental enforcement (Wang \& Jin, 2007), they shoulder more social responsibilities and are inclined to reduce emissions under the pressure of public opinion. So the total environmental effects of SOEs are not significantly different from those of non-SOEs.

We also investigate the effects of macroeconomic variables. Our estimated result in Column (1) shows that both of population density and GDP per capita fails to pass the $10 \%$ level of significance test, implying that population density and GDP per capita exerts no 
remarkable influence on firms' pollution discharges. The estimated results in Table 2 also demonstrate that the coefficients of industrial structure (Manufacturing) is negative and significant at the 5\% level, indicating that industrial structure is negatively related to firms' pollution discharges. It may be that many industries in the secondary sector have transformed to high-tech processed and cleaner production, and that the new approach towards industrialization featured by the coordination between economic development and environmental protection has shown positive effects.

Table 2 Regression of Political Connects on Firms’ Pollution Intensity

\begin{tabular}{|c|c|c|c|c|}
\hline \multirow{2}{*}{ Variables } & \multicolumn{4}{|c|}{ Dependent variable: SO2 } \\
\hline & $(1)$ & $(2)$ & (3) & (4) \\
\hline Constant & $\begin{array}{c}2.5002^{* * *} \\
(0.6011)\end{array}$ & $\begin{array}{c}2.5110^{* * *} \\
(0.5917)\end{array}$ & $\begin{array}{c}2.5904 * * * \\
(0.5798)\end{array}$ & $\begin{array}{c}2.5207 * * * \\
(0.5981)\end{array}$ \\
\hline Political & $\begin{array}{c}0.3174 * * \\
(0.1293)\end{array}$ & $\begin{array}{c}0.5495^{* *} \\
(0.2397)\end{array}$ & $\begin{array}{c}2.7146 * * * \\
(0.5330)\end{array}$ & $\begin{array}{l}0.6748 * \\
(0.3520)\end{array}$ \\
\hline Liability & $\begin{array}{l}-0.1673 \\
(0.1152)\end{array}$ & $\begin{array}{l}-0.1657 \\
(0.1152)\end{array}$ & $\begin{array}{l}-0.1632 \\
(0.1158)\end{array}$ & $\begin{array}{l}-0.1729 \\
(0.1153)\end{array}$ \\
\hline Profitability & $\begin{array}{c}-0.3812 * * \\
(0.1839)\end{array}$ & $\begin{array}{c}-0.3739 * * \\
(0.1818)\end{array}$ & $\begin{array}{c}-0.3910 * * \\
(0.1841)\end{array}$ & $\begin{array}{c}-0.3813^{* *} \\
(0.1834)\end{array}$ \\
\hline Scale & $\begin{array}{c}-0.0274 * * \\
(0.0123)\end{array}$ & $\begin{array}{c}-0.0266^{* *} \\
(0.0122)\end{array}$ & $\begin{array}{c}-0.0272 * * \\
(0.0123)\end{array}$ & $\begin{array}{c}-0.0274^{* *} \\
(0.0122)\end{array}$ \\
\hline Ownership & $\begin{array}{l}-0.0798 \\
(0.0780)\end{array}$ & $\begin{array}{l}-0.0798 \\
(0.0777)\end{array}$ & $\begin{array}{c}-0.0778 \\
(0.0783)\end{array}$ & $\begin{array}{c}-0.0812 \\
(0.0786)\end{array}$ \\
\hline Population & $\begin{array}{l}-0.0002 \\
(0.0005)\end{array}$ & $\begin{array}{l}-0.0003 \\
(0.0005)\end{array}$ & $\begin{array}{l}-0.0002 \\
(0.0005)\end{array}$ & $\begin{array}{l}-0.0002 \\
(0.0005)\end{array}$ \\
\hline Pgdp & $\begin{array}{l}-0.0305 \\
(0.0706)\end{array}$ & $\begin{array}{l}-0.0386 \\
(0.0705)\end{array}$ & $\begin{array}{l}-0.0126 \\
(0.0660)\end{array}$ & $\begin{array}{l}-0.0316 \\
(0.0691)\end{array}$ \\
\hline Pgdp2 & $\begin{array}{c}0.0010 \\
(0.0044)\end{array}$ & $\begin{array}{c}0.0014 \\
(0.0043)\end{array}$ & $\begin{array}{l}-0.0001 \\
(0.0041)\end{array}$ & $\begin{array}{c}0.0010 \\
(0.0043)\end{array}$ \\
\hline Manufacturing & $\begin{array}{c}-2.0701 * * \\
(0.8355)\end{array}$ & $\begin{array}{c}-2.0027 * * \\
(0.8324)\end{array}$ & $\begin{array}{c}-2.1871 * * * \\
(0.7920)\end{array}$ & $\begin{array}{c}-2.0302^{* *} \\
(0.8230)\end{array}$ \\
\hline Misallocation & & $\begin{array}{c}0.0010^{* * *} \\
(0.0003)\end{array}$ & & \\
\hline Political $\times$ Misallocation & & $\begin{array}{c}0.6869 * * \\
(0.2857)\end{array}$ & & \\
\hline Regulation & & $\begin{array}{l}-0.1385^{*} \\
(0.0757)\end{array}$ & & \\
\hline
\end{tabular}




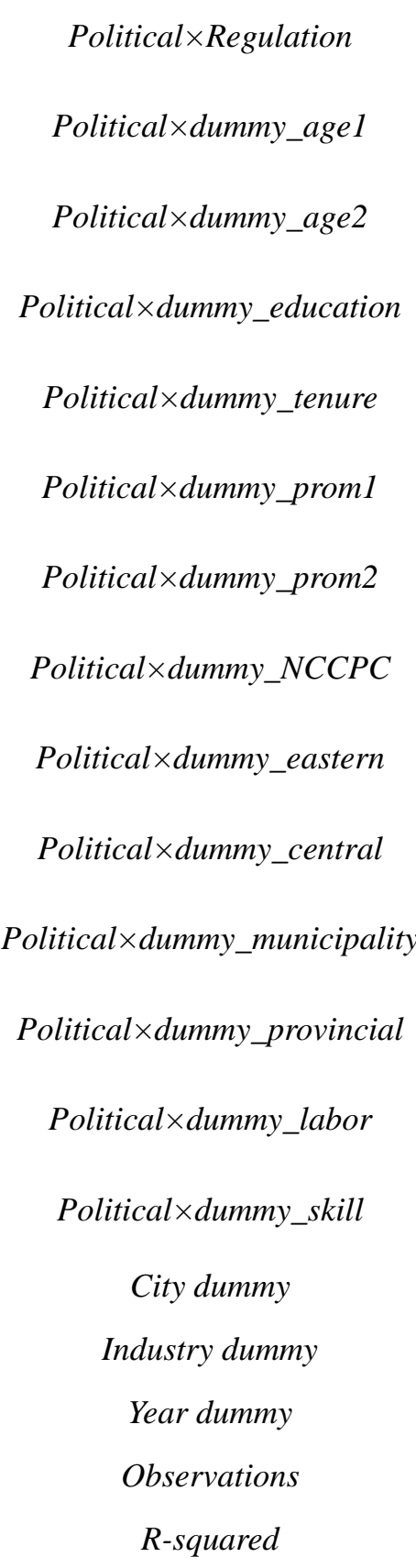

$\begin{array}{cc}\text { Yes } & \text { Yes } \\ \text { Yes } & \text { Yes } \\ \text { Yes } & \text { Yes }\end{array}$

Yes

Yes

Yes

Yes

Yes

Yes

$15,238 \quad 15,238$

15,238

15,238

0.1251

0.1259

0.1280

0.1269

Note: Standard errors clustered at city level are shown in parentheses. *, ** and *** indicate significance at the $10 \%, 5 \%$ and $1 \%$ levels, respectively.

We also investigate the channels through which political connections influence the environment and present the results in Column (2), Table 2. The estimated results show that the coefficients of political connections are significantly positive, which is consistent with those in baseline regressions. Investment expansion (Investment) is introduced into Column (2), Table 2, and the result indicates that the coefficient of Investment is significantly positive, 
demonstrating that investment expansion is counterproductive for emission reduction efforts. The coefficient for the interaction term Political $\times$ Investment is positive and significant at the $5 \%$ levels, indicating that the investment expansion of politically connected firms remarkably raises their pollution discharges. One possible explanation might be that the scale effects of investment expansion decrease gradually under the influence of political connections, and firms need more energy and resources and thus cause more emissions.

In addition, the estimated result in Column (2) demonstrates that the coefficient of Regulation is significantly negative, suggesting that environmental regulation can remarkably reduce pollution discharges. However, the coefficient of Political $\times$ Regulation is positive at the $5 \%$ significance level. This result suggests that, as politically connected firms have access to the means to loosen environmental regulation, the effect of environmental regulation is actually diluted significantly. Thus, Hypothesis 2a and Hypothesis 2b are also supported.

\subsection{Effects of Politicians’ Heterogeneous Background}

In this section, we divide our sample into several sub-samples according to the characteristics of officials and examine potential variation in the relationship between political connections and industrial pollution in different groups. The cross terms of political connections and dummy variables of individual characteristics are incorporated into the models in the following analysis.

To reflect the effect of age, the cross terms of political connections and age-specific dummy variables are included in regressions. Specifically, dummy_age1 takes the value of one if the mayors are between 50 and 55 years and zero otherwise; dummy_age2 takes the 
value of one if the mayors are 55 years old or above and zero otherwise. The estimation results in Column (3) of Table 2 indicate the environment is mostly negatively affected by political connections with officials under 50 years old. It is found that the coefficient of Political $\times$ dummy_age 1 is -0.1344 while the coefficient of Political $\times$ dummy_age2 is -0.6487 , both of which pass the $5 \%$ significance test. Thus, the pollution shelter effects caused by political connections with officials under 50 years old is 0.1344 higher than those associated with officials between 50 and 55 years old while 0.6487 higher than those associated with officials who are 55 years old or above. These findings further support our Hypothesis 3a.

Column (3) also considers sub-samples according to officials' educational background. The cross term between political connections and dummy variable capturing education differences is incorporated in the regressions. The dummy_education takes the value of one for local officials with bachelor degree or above and zero otherwise. The coefficient of the cross term between political connections and education dummy variables in Column (3) is -1.2168 and significant at the 5\% level. This implies that pollution discharges induced by political connections through officials with a bachelor degree or above are 1.2168 lower than those associated with officials who receive high-school education or below. Thus, officials with higher education may have better professional skills and knowledge which help them understand the importance of sustainable development. This further supports our Hypothesis 3b.

The tenure of office may affect a local official's willingness to maintain political connections. As the mayors serve no more than two consecutive terms, or ten years in total, 
we create dummy_tenure which is equal to one if the mayors served for five years or below. The empirical results in Column (3) show that the negative effects of political connections with long-tenure officials are clearly greater than those with short tenure. Specifically, if the officials serve no more than five years, their political connections will be responsible for fewer pollution discharges than long-tenure officials. This result is consistent with Persson and Zhuravskaya (2012) and further confirms our Hypothesis 3c.

In addition, how local officials are promoted may reflect their past career and experience (which influence their political ambitions). Thus, we sub-divide the sample according to whether the officials are locally promoted, externally promoted or through parallel move ${ }^{1}$. Therefore, two dummy variables are incorporated in the regression to reflect the mayors' turnover type. Specifically, dummy_prom1 takes the value of one if officials are externally promoted and zero otherwise; dummy_prom2 takes the value of one if officials belong to the parallel move category and zero otherwise. The estimated results in Column (3) of Table 2 show that the cross term between political connections and dummy_prom1 (Political $x$ dummy_prom1) is negative and significant at the $1 \%$ level, indicating political connections between officials who are externally promoted have smaller negative effects on the environment. This may be because officials promoted locally are more likely to get support from local elites and form alliances with them, according to Persson and Zhuravskaya (2012). It is much easier for them to form political connections and manipulate environmental regulations. What is noteworthy is that the estimation results in Column (3) reveal that the

\footnotetext{
${ }^{1}$ Parallel move, or lateral move, refers to the case of a mayor being transferred to another city or a new position at the same rank. This definition is consistent with that by Li \& Zhou (2005) and Kanbur \& Zhang (2009).
} 
coefficient of the cross term (Political $x d u m m y \_p r o m 2$ ) is negative at the $10 \%$ significance level, implying that the intensity of pollution discharges induced by political connections with parallel-moved officials tends to be much smaller than that with locally promoted officials. These results fully support Hypothesis 3d that the negative effects of political connections on firms’ pollution discharges are more profound if officials are promoted locally.

To capture possible changes before and after the $18^{\text {th }}$ Congress, dummy_NCCPC is defined to take the value of one for the post-congress period. Column (3) shows that the coefficient of the cross term between political connections and dummy_NCCPC is negative but fails to pass the $10 \%$ significance test, suggesting that the pollution shelter effects caused by political connections do not decrease remarkably after the $18^{\text {th }}$ NCCPC. It is worth noting that any policy has time-lag effects. It can be found if we define dummy_NCCPC equals to one when the $18^{\text {th }}$ NCCPC was held after two years or longer. Then the coefficient of the cross term Political $\times$ dummy_NCCPC is negative and significant at the $5 \%$ levels. Thus, it can be inferred that firms' incentives to establish political connections are lower along with thoroughly implement of anti-corruption campaign and their capacities to reduce emissions are improved.

\subsection{Effects of Firm Heterogeneity}

Significant differences exist among regions with different development conditions, such as government policies and resource endowment. Two dummy variables identifying central and western areas are introduced to examine the location effects on environmental pollution and the estimated results are shown in Column (4) of Table 2. It is noted that politically 
connected firms in the eastern areas generate the least pollutant emission than those in the central and western areas. This could be because a better legal environment in the eastern regions makes it more difficult for polluting firms to establish political connections with local officials and hence restrains excessive pollution discharges. Thus, our hypothesis $4 \mathrm{a}$ is supported.

The estimation models according to different city hierarchy are presented in Column (4) of Table 2, too. Dummy_municipality denotes whether the city is a municipality or not, and dummy_province indicates whether the city is a provincial capital or not. The estimated results show that pollution discharges of politically connected firms in prefecture cities are obviously higher than those located in municipalities and provincial capitals. It may be that municipalities and provincial capitals have more preferential policies and financial support from central government and their environmental regulation is more stringent than prefecture cities. Prefecture cities remain relatively underdeveloped in terms of economic and social development. In order to pursue rapid development and more fiscal revenues, local officials may blindly accept high energy-consuming and high-polluting firms, and even act as a protector for polluting firms. Thus, our Hypothesis $4 \mathrm{~b}$ is full verified.

The environmental effects of political connections vary among different industries too. The cross terms of political connections and industrial dummy variables are incorporated in the regressions. The dummy_labor and dummy_skill variables indicate the firms in labor-intensive and skill-intensive sectors, respectively. The estimated results in Column (4) illustrate that pollution discharges in capital-intensive industries are most negatively affected 
by political connections, followed by labor-intensive industries. For example, the coefficients of the cross term between political connections and industrial dummies in Column (4) reveal that pollution discharges of politically connected firm in labor-intensive industries are 0.7501 lower than capital-intensive firms, while pollution discharges of politically connected firm in skill-intensive industries are 0.8326 lower than capital-intensive ones. Thus, the pollution shelter effects caused by political connections are more obvious in capital-intensive industries, which is in line with our Hypothesis 4c.

\subsection{Robustness Tests}

In this section we conduct a set of robustness tests to confirm that our main results hold after alternative specifications are considered.

\subsubsection{Alternative measures for political connections and environmental pollution}

The first modification considers three optional pollution indices, namely the intensity of industrial COD and waste water emissions. In addition, given that more than one top manager share the same birthplace as the mayor in whose district the firm is located, we construct a variable Polcon and use the number of top managers who are politically connected with the appointed officials to measure the intensity of political connections. Besides, political connections are defined according to the provincial birthplaces as well as education institutions. Moreover, a proxy variable $(P B)$ is used to reflect the political background of a firm's top manager who is currently serving or has formerly served in the government, or as a

National People's Congress (NPC) delegate or a Chinese People’s Political Consultative 
Conference (CPPCC for short) member. The similar concept was adopted by Fan et al. (2008) and Cai \& Sevilir (2012).

The estimated results in Table 3, imply the same set of inferences we obtained from our baseline specification. That is, the estimation results in terms of signs and significance tests are similar to those previously presented and hence robust under alternative indices. In particular, the estimated results in Column (3) of Table 3 show the coefficient of Polcon is 0.3197 and significant at the $5 \%$ level, which is 0.0023 higher than the coefficient of political connections in our baseline model. This implies that the higher the intensity of political connections, the more pollution discharges the politically connected firms will emit. Additionally, Column (5) show that the coefficient of political connections based on education institutions is significant and positive, and its magnitude is much smaller than those in the "birthplace" specifications, confirming that the "same birthplace" relationship plays a more important role in strategic emissions. This reflects Chinese cultural tradition that connections through hometowns are more prominent in personal networks. Thus political connection, based on "birth place" identity, provides protection for the polluters and causes more serious damage to the environment.

Table 3 Robustness Checks: Alternative Measures for Political Connections and Pollution Intensity

\begin{tabular}{|c|c|c|c|c|c|c|}
\hline \multirow{2}{*}{ Variables } & \multirow{2}{*}{$\begin{array}{c}\text { COD } \\
(1)\end{array}$} & \multirow{2}{*}{$\begin{array}{c}\text { water } \\
(2)\end{array}$} & \multicolumn{4}{|c|}{$\mathrm{SO} 2$} \\
\hline & & & (3) & (4) & (5) & (6) \\
\hline Constant & $\begin{array}{l}-1.3197 \\
(1.1747)\end{array}$ & $\begin{array}{c}-0.3346 * * \\
(0.1943)\end{array}$ & $\begin{array}{c}2.5009 * * * \\
(0.6011)\end{array}$ & $\begin{array}{c}2.4997 * * * \\
(0.6008)\end{array}$ & $\begin{array}{c}2.5635 * * * \\
(0.5992)\end{array}$ & $\begin{array}{c}2.5299 * * * \\
(0.5981)\end{array}$ \\
\hline Political & $\begin{array}{c}0.2881^{* *} \\
(0.1419)\end{array}$ & $\begin{array}{c}0.3039 * * \\
(0.1397)\end{array}$ & & & & \\
\hline Polcon & & & $\begin{array}{c}0.3197 * * \\
(0.1268)\end{array}$ & & & \\
\hline Political_province & & & & $\begin{array}{c}0.3271 * * * \\
(0.1191)\end{array}$ & & \\
\hline
\end{tabular}


Political_school

$P B$

$0.1034^{*}$

(0.0527)

\begin{tabular}{ccccccc} 
Control variables & Yes & Yes & Yes & Yes & Yes & Yes \\
Year dummy & Yes & Yes & Yes & Yes & Yes & Yes \\
City dummy & Yes & Yes & Yes & Yes & Yes & Yes \\
Industry dummy & Yes & Yes & Yes & Yes & Yes & Yes \\
\hline Observations & 14,951 & 14,833 & 15,238 & 15,238 & 15,238 & 15,238 \\
R-squared & 0.1789 & 0.1910 & 0.1250 & 0.1251 & 0.1248 & 0.1249 \\
\hline
\end{tabular}

Note: The dependent variables are listed in the first row. Political connections in Column (5) are constructed according to the provincial birthplace and those in Column (6) according to education institutions. Standard errors clustered at city level are shown in parentheses. *, ** and *** indicate significance at the $10 \%, 5 \%$ and $1 \%$ levels, respectively.

\subsubsection{The effect of outliers}

As for the second modification, all continuous variables are winsorized at the top and bottom one percent to remove the effect of outliers according to Crinò and Ogliari (2017). Besides, SO2 intensity is censored at $1 \%$ in each tail to adjust the abnormal values. The results listed in Columns (1)-(2), Table 4 suggest the same set of inferences as we obtained from our baseline specification. That is, the estimation results in terms of the sign and significance are similar to those previously presented.

Table 4 Robustness Checks: Removing the Effect of Outliers and Endogeneity Test

\begin{tabular}{cccccc}
\hline \multirow{2}{*}{ Variables } & \multicolumn{5}{c}{ Dependent variable: SO2 } \\
& $(1)$ & $(2)$ & $(3)$ & $(4)$ & $(5)$ \\
\hline \multirow{2}{*}{ Constant } & $2.8701^{* * *}$ & $2.2376^{* * *}$ & $2.5405^{* * *}$ & $2.5042^{* * *}$ & $2.3784^{* * *}$ \\
& $(0.6272)$ & $(0.5020)$ & $(0.6690)$ & $(0.6012)$ & $(0.5256)$ \\
Political & $0.3116^{* *}$ & $0.3055^{* * *}$ & $0.3167^{* *}$ & & \\
& $(0.1240)$ & $(0.1105)$ & $(0.1287)$ & & \\
Match & & & $0.3155^{* * *}$ & \\
& & & $(0.1295)$ & \\
Political_IV & & & & $0.1994^{*}$ \\
& & & & \\
imr & & -0.0253 & &
\end{tabular}




\begin{tabular}{cccccc} 
Control variables & Yes & Yes & Yes & Yes & Yes \\
Year dummy & Yes & Yes & Yes & Yes & Yes \\
City dummy & Yes & Yes & Yes & Yes & Yes \\
Industry dummy & Yes & Yes & Yes & Yes & Yes \\
\hline Observations & 15,238 & 15,085 & 15,238 & 15,235 & 15,238 \\
R-squared & 0.1284 & 0.1162 & 0.1251 & 0.1250 & - \\
\hline
\end{tabular}

Note: All continuous variables are winsorized at the top and bottom one percent in Column (1), and SO2 intensity are censored at $1 \%$ in each tail in Column (2). Column (3) presents the results for the endogeneity test using Heckman's two-stage procedure; Column (4) presents the results for the endogeneity test using PSM procedure; Column (5) presents the results for the endogeneity test using two-stage least square regression. Standard errors clustered at city level are shown in parentheses. *, ** and *** indicate significance at the $10 \%, 5 \%$ and $1 \%$ levels, respectively.

\subsubsection{Endogeneity Tests}

The possible existence of endogeneity may be problematic. First, the causal relationship between political connections and industrial pollution may be bidirectional. Firstly, polluting firms are very keen to obtain protection by searching for political resources and government support (Rodrigue et al., 2013). In this case, an increase in pollution discharges may lead to more political connections. Second, although we have controlled for other important variables influencing industrial discharges, we cannot rule out the endogeneity issue caused by omitted variables which may be related to political connections. We adopt three different approaches, namely Heckman's two-stage procedure, propensity score matching (PSM) method as well as two-stage least square regression to deal with endogeneity.

The two-stage procedure of Heckman (1979) involves the estimation of a probit model of political connections, the inverse Mills ratio (imr for short) and the inclusion of imr in the pollution equations as a control variable. In the first stage, we perform a probit regression with Political as the dependent variable. According to Boubakri et al. (2008), GDP per capita (Pgdp) and the absolute value of fiscal deficit (Deficit) are incorporated into the probit model 
as the city-levle control variables. We also control for firm characteristics (such as liability, profitability, scale and ownership) to assess the possible motives of firms in building political connections. The resulting inverse Mills ratio (imr) is incorporated into the second-stage regression to correct any potential bias. Column (3) of Table 4 presents the estimated results of the second-stage regression which show that the coefficient of political connections is still positive and significant at 5\%. Thus, the main conclusions still hold, namely, political connections increase firms’ pollution discharges.

Moreover, we use a PSM method to address self-selection bias. The key to propensity score matching is to identify treatment and control groups. The treatment group consists of politically connected firms (Political=1) and other firms as the control group (Political=0). Our control sample is selected by nearest neighboring logit propensity score one-to-one matching strategy with a set of macro-level and firm-level characteristics including Pgdp, Deficit, Liability, Profitability, Scale and Ownership. Hence, each firm with no political connection is matched with a politically connected firm with the closest propensity score without replacement on the basis of these variables. We calculate the difference and its t-statistic between the treatment and control groups in terms of each of the above variables, and find that the biases of all variables are less than $10 \%$ after matching, and t-statistics do not reject the null hypothesis that there are no differences between treatment and control groups after matching. Then the variable Match is an indicator variable which is equal to one if the firm is in the treatment group and zero if it is in the control group. The coefficient of Match in Column (4) of Table 4 is positive and significant at the $1 \%$ level, indicating that the pollution discharges by politically connected firms are higher than those by firms with no political connection.

To address the endogenous problems resulting from omitted variables, we estimate a 
two-stage least square regression using the employment rate (Employment) as the instrument for political connections. The employment rate is defined as the percentage of the total labor force that is employed in the city where the firm is located. Government intervention is more common in cities with a higher employment rate and thus firms are easier to seek for political connections (Bollinger \& Ihlanfeldt, 2003; Kondo \& Shigeoka, 2017; Tahoun \& Lent, 2017). Therefore, the employment rate variable is positively associated with political connections. However, there is no evidence indicating that this instrument directly affects firms' pollution discharges (Su et al., 2018). We firstly regress the indicator variable for political connections on the instrumental variable and other control variables. By doing so, we can compute a residual Political variable (called Political_IV). Then we conduct the second-stage regression using Political_IV as the measure for political connections. As shown in Column (5) of Table 4, the estimated result shows that the coefficient of Political_IV is positive and significant at the $10 \%$ level, indicating that our main findings still hold after potential endogenous problems are considered by using an instrumental approach. Following Kleibergen \& Paap (2006), we perform an underidentification test and weak-identification test to verify the validity of instrumental variables. LM test is 13.561 and rejects underidentification at the $1 \%$ significance level, while Wald F test is 18.544 and rejects the null hypothesis that our instruments are weak at the $10 \%$ levels. Overall, the conclusion that political connections significantly increase firms' pollution discharges is still valid after the consideration of endogeneity problems by using various methods.

\section{Conclusions and Remarks}

The frequent haze episodes and high pollution emissions have become severe issues faced by the Chinese policy-makers. Though there are studies in this field, they cannot explain why environmental enforcement is even laxer as emission reduction targets proposed 
by central and local governments become more stringent. By merging datasets of Chinese officials and micro-firms covering the period of 2007-2015, we analyse how political connections between politicians and top managers influence pollution discharges. The empirical results show that political connections are the institutional origin that causes firms to adopt strategic pollution discharges. Political connections significantly increase firms' pollution discharges, and this result is still valid after a series of robustness checks and consideration of endogeneity problems by using different methods.

We also pay special attention to the role of individual characteristics in moderating the relationship between political connections and pollution discharges. The estimation results by sub-samples reveal that local officials with less education, a younger age, longer tenure and local promotion are more likely to establish political connections, which results in regulatory violation and excessive emissions. Empirical results also show that the pollution shelter effects caused by political connections are more obvious in central and western regions, prefecture cities and capital-intensive industries.

Our findings not only provide empirical evidence for understanding the relationship between political connections and industrial pollution, but also have important policy implications for cadre management and firm governance reforms. The central government should formulate reasonable incentive mechanisms to properly handle the relationship between economic growth and environmental protection. Apart from the green GDP accounting system and multiple standards in political promotion, sound accountability and supervision mechanisms should be established in order to reduce the possibility of collusion 
between local officials and top managers of polluting firms. Moreover, local governments should make greater effort to transform from their traditional role of business control and intervention to service-provision and regulatory support so that environmental policies can be effectively implemented. As for firm governance, the environmental information disclosure system of listed companies should be strengthened and corporate environmental responsibilities should be strictly monitored.

While offering a new perspective on identifying the environmental effects of political connections, our study has limitations that represent opportunities for further research. In particular, our empirical results reveal that politically connected firms produce more pollution than their counterparts, but it would be more compelling to investigate whether politically unconnected firms turn to emit more pollution discharges after they are able to form political connections with local politicians, or how firms' pollution discharges change after they lose political connections. This is a potential topic for follow-up research when relevant data are available. In addition, although this study identifies the environmental effect of political connections and uncovers the variation across different regions, industries and politicians, we cannot distinguish different roles of top managers in forming political connections.

\section{Compliance with Ethical Standards:}

Funding: This work was funded by the National Natural Science Foundation of China [grant number 71703035] and China Scholarship Council (File No.201706135020).

Ethical approval: This article does not contain any studies with human participants or animals performed by any of the authors. 


\section{References}

Acemoglu, D.,Johnson,S., Robinson, J., \& Thaicharoen, Y. Y. (2003). Institutional Causes, Macroeconomic Symptoms: Volatility, Crises and Growth. Journal of Monetary Economics, 50, 49-123.

Adams, R., Hermalin, B. E., \& Weisbach, M. S. (2010). The Role of Boards of Directors in Corporate Governance: A Conceptual Framework and Survey. Journal of Economic Literature. 48 (1), 58-107.

Aggarwal, R., Erel, I., Ferreira, M., \& Matos, P. (2011). Does Governance Travel Around the World? Evidence from Institutional Investors. Journal of Financial Economics, 100(1), 154-181.

Albert, V. \& Wouter, E. (2011). Institutions and the Relation between Corruption and Economic Growth. Review of Development Economics, 15(1), 108-123.

Amore, M. D. \& Bennedsen, M. (2013). The Value of Lcal Political Connections in a Low-Corruption Environment. Journal of Financial Economics. 110 (2), 387-402.

Bach, T. \& Veit, S. (2018). The Determinants of Promotion to High Public Office in Germany: Partisan Loyalty, Political Craft, or Managerial Competencies? Journal of Public Administration Research and Theory, 28(2), 254-269.

Badinger, H. \& Nindl, E. (2014). Globalisation and Corruption, Revisited. The World Economy, 37(10), $1424-1440$.

Baltagi, B. H. (2001). Econometric Analysis of Panel Data. Wiley and Sons Ltd.

Banzhaf, H. S. \& Chuppd, A. (2012). Fiscal Federalism and Interjurisdictional Externalities, New Results and an Application to US Air Pollution. Journal of Public Economics, 96(5-6), 449-464.

Baranchuk, N., Kieschnick, R., \& Moussawi, R. (2014). Motivating Innovation in Newly Public Firms. Journal of Financial Economics, 111(3), 578-588.

Barbosa, N. \& Faria, A. P. (2011). Innovation across Europe: How Important are Institutional Differences? Research Policy, 40(9), 1157-1169.

Barnes, B. R., Yen, D., \& Zhou, L. (2011). Investigating Guanxi Dimensions and Relationship Outcomes: Insights from Sino-anglo Business Relationships. Industrial Marketing Management, 40, 510-521. 
Benarroch, M. \& Thille, H. (2001). Transboundary Pollution and the Gains from Trade. Journal of International Economics, 55(1), 139-159.

Berger, R., Herstein, R., Silbiger, A., \& Barnes, B. R. (2018). Is Guanxi Universal in China? Some Evidence of A Paradoxical Shift. Journal of Business Research, 86, 344-355.

Bertrand, M., Schoar, A., Thesmar, D., \& We, C. (2007). Politicians, Firms and the Political Business Cycle, Evidence from France. Chicago, University of Chicago.

Bertand, M., Kramarz, F., \& Schoar, A. (2018). The Cost of Political Connections. Review of Finance, 21(3), 849-876.

Berkman, H., Cole, R. A., \& Fu, L. J. (2010). Political Connections and Minority-Shareholder Protection: Evidence from Securities-Market Regulation in China. The Journal of Financial and Quantitative Analysis, 45(6), 1391-1417.

Blau, B., Brough, T., \& Thomas, D. (2013). Corporate Lobbying, Political Connections, and the Bailout of Banks. Journal of Banking and Finance, 37(8), 3007-3017.

Bliss, M. A. \& Gul, F. A. (2012). Political Connection and Cost of Debt, Some Malaysian Evidence. Journal of Banking and Finance, 36(5), 1520-1527.

Bollinger, C. \& Ihlanfeldt, K. (2003). The Intraurban Spatial Distribution of Employment: Which Government Interventions Make a Difference? Journal of Urban Economics, 53(3), 396-412.

Boly, A. \& Gillanders, R. (2018). Anti-corruption policy making, discretionary power and institutional quality: An experimental analysis. Journal of Economic Behavior \& Organization, 152, 314-327.

Borghesi, S., Cainelli, G., \& Mazzanti, M. (2015). Linking Emission Trading to Environmental Innovation: Evidence from the Italian mManufacturing Industry. Research Policy, 44(3), 669-683.

Boubakri, N., Cosset, J., \&Saffar, W. (2008). Political Connections of Newly Privatized Firms. Journal of Corporate Finance,14(5),654-673.

Boubakri, N., Guedhami, O., Mishra, D., \& Saffar, W. (2012). The Impact of Political Connections on Firms’ Operating Performance and Financial Decisions. Review of Financial Economics, 35(3), 397-423. 
Brollo, F., Nannicini, T., Perotti, R., \& Tabellini, G. (2013). The Political Resource Curse. American Economic Review, 103(5), 1759-1796.

Brunel, C. \& Levinson, A. (2016). Measuring the Stringency of Environmental Regulations. Review of Environmental Economics and Policy, 10(1), 47-67.

Bu, M. \& Wagner, M. (2016). Racing to the Bottom and Racing to the Top, the Crucial Role of Firm Characteristics in Foreign Direct Investment Choices. Journal of International Business Studies, 47(9), 1032-1057.

Cai, H. B. \& Treisman, D. (2006). Did Government Decentralization Cause China's Economic Miracle? World Politics, 58(4), 505-535.

Cai,Y. \& Sevilir, M. (2012). Board Connections and M\&A Transactions. Journal of Financial Economics, 03(2), 327-349.

Cerqua, A. \& Pellegrini, G. (2014). Do Subsidies to Private Capital Boost Firms' Growth? A Multiple Regression Discontinuity Design Approach. Journal of Public Economics, 109, 114-12.

Chan, E. H. W., \& Suen, H. C. H. (2005). Dispute Resolution Management for International Construction Projects in China. Management Decision, 43, 589-602.

Chen, L., Wang, Y.P.,\& Wu, L.S. (2016). Political Connections and Tax-induced Earnings Management, Evidence from China. The European Journal of Finance, 22(4-6), 413-431.

Chen, T. \& Kung, J. K. (2016). Do Land Revenue Windfalls Create A Political Resource Curse? Evidence from China. Journal of Development Economics, 123, 86-106.

Cheng, L. (2018). Estimating the Value of Political Connections in China: Evidence from Sudden Deaths of Politically Connected Independent Directors. Journal of Comparative Economics, 46, 495-514.

Choi, Y., Song, M. L., \& Myeong, S. (2018). Sustainable Governance in Northeast Asia: Challenges for Innovation Frontier. Switzerland: Multidisciplinary Digital Publishing Institute.

Chung, S. (2014). Environmental Regulation and Foreign Direct Investment, Evidence from South Korea. Journal of Development Economics, 108(C), 222-236.

Claessens, S., Feijen, E., \& Laeven, L. (2008). Political Connections and Preferential Access to Finance: 
the Role of Campaign Contributions. Journal of Financial Economics, 88, 554-580.

Cole, M. A., Elliott, R. J., \& Okubo, T. (2010). Trade, Environmental Regulations and Industrial Mobility: An Industry-level Study of Japan. Ecological Economics, 1995-2002.

Cole, M. A., Elliott, R. J., Okubo, T., \& Zhou, Y. (2013). The Carbon Dioxide Emissions of Firms: A Spatial Analysis. Journal of Environmental Economics and Management, 65(2), 290-309.

Cooper, M. J., Gulen, H., \& Ovtchinnikov, A. (2010). Corporate Political Contributions and Stock Returns. Journal of Finance, 65(2), 687-724.

Crinò, R. \& Ogliari, L. (2017). Financial Imperfections, Product Quality and International Trade. Journal of International Economics, 104(3), 63-84.

Cull, R., Li, W., Sun, B., \& Xu, C. (2015). Government Connections and Financial Constraints: Evidence from a Large Representative Sample of Chinese Firms. Journal of Corporate Finance, 32, 271-294.

Do, Q. A., Lee, Y. T., \& Nguyen, B. D. (2015). Political Connections and Firm Value: Evidence from the Regression Discontinuity Design of Close Gubernatorial Elections. CEPR Discussion Paper No. 10526

Donelli, M., Larrain, B. \& Francisco U. Ownership Dynamics with Large Shareholders: An Empirical Analysis. Journal of Financial and Quantitative Analysis, 48(2), 579-609.

Dong, B. M., Gong, J., \& Zhao, X. (2015). FDI and Environmental Regulation, Pollution Haven or Race to the Top? Journal of Regulatory Economics, 41(2), 216-237.

Duchin, R. \& Sosyura, D. (2012). The Politics of Government Investment. Journal of Financial Economics, 106(1), 24-48.

Earnhart, D. \& Lizal, L. (2006). Effects of Ownership and Financial Performance on Corporate Environmental Performance. Journal of Comparative Economics, 34(1), 111-129.

Eaton, S. \& Kostka, G. (2014). Authoritarian Environmentalism Undermined? Local Leaders' Time Horizons and Environmental Policy Implementation in China. The China Quarterly, 218, 359-380.

Eaton, S. \& Kostka, G. (2017). Central Protectionism in China: The "Central SOE Problem” in Environmental Governance. The China Quarterly, 231, 685-704. 
Elliott, R. J. \& Shimamoto, K. (2008). Are ASEAN Countries Havens for Japanese Pollution-Intensive Industry? The World Economy, 31(2), 236-254.

Engelberg, J., Gao, P. J., \& Parsons, C. A. (2013). The Price of a CEO’s Rolodex. The Review of Financial Studies, 26 (1), 79-114.

Faccio, M. (2010). Differences between Politically Connected and Nonconnected Firms, A Cross-Country Analysis. Financial Management, 39(3), 905-928.

Faccio, M. (2006). Politically Connected Firms. American Economic Review, 96(1), 369-386.

Fan, J. P., Rui, O.M., \& Zhao, M. (2008). Public Governance and Corporate Finance, Evidence from Corruption Cases. Journal of Comparative Economics, 36(3), 343-364.

Farashahi, M. \& Hafsi, T. (2009). Strategy of Firms in Unstable Institutional Environments. Asia Pacific Journal of Management, 26(4), 643-666.

Feng, L., B., Fu,T.,\& Kutan, A. M. (2019). Can Government Intervention be Both a Curse and a Blessing? Evidence from China's Finance Sector. International Review of Financial Analysis, 61, 71-81..

Ferris, S. P., Houston, R., \& Javakhadze, D. (2016). Friends in the Right Places: The Effect of Political Connections on Corporate Merger Activity. Journal of Corporate Finance, 41, 81-102.

Firth, M., Malatesta, P. H., Xin, Q., \& Xu, L. P. (2012). Corporate investment, government control, and financing channels: Evidence from China's Listed Companies. Journal of Corporate Finance, 18(3), 433-450.

Forslid, R., Okubo, T., \& Ulltveit-Moe, K. H. (2018). Why are Firms that Export Cleaner? International Trade, Abatement and Environmental Emissions. Journal of Environmental Economics and Management, 91, 166-183.

Fredriksson, P. \& Svensson, J. (2003). Political Instability, Corruption and Policy formation: the Case of Environmental Policy. Journal of Public Economics, 87(7-8), 1383-1405.

Freeman, J. \& Kolstad, C. D. (2006). Moving to Markets in Environmental Regulation: Lessons from Twenty Years of Experience. London: Oxford University Press.

Ghanem, D. \& Zhang, J. (2014). Effortless Perfection: Do Chinese Cities Manipulate Air Pollution Data? 
Journal of Environmental Economics and Management, 68(2), 203-225.

Glaeser, E. \& Saks, R. E. (2006). Corruption in America. Journal of Public Economics, 90,1053-1072.

Goldman, E., Rocholl, J., \& So, J. (2009). Do Politically Connected Boards Affect Firm Value? Review of Financial Studies, 22 (6), 2331-2360.

Goldman, E., Rocholl, J., \& So, J. (2013). Politically Connected Boards of Directors and the Allocation of Procurement Contracts. Review of Finance, 17(5), 1617-1648.

Gray, W. B. \& Shadbegian, R. J. (2004).Optimal Pollution Abatement, Whose Benefits Matter, and How Much? Journal of Environmental Economics and Management, 47(3), 510-534.

Gray, W. B. \& Shimshack, J. P. (2011). The Effectiveness of Environmental Monitoring and Enforcement: A Review of the Empirical Evidence. Review of Environmental Economics and Policy, 5(1), 3-24.

Grossman, G. M. \& Krueger, A. B. (1995). Economic Growth and the Environment.The Quarterly Journal of Economics, 110(2), 353-377.

Guo, Y., Rammal, H. G., Benson, J., Zhu, Y., \& Dowling, P. J. (2018). Interpersonal Relations in China: Expatriates' Perspective on the Development and Use of Guanxi. International Business Review, 27, 455-464.

Halkos, G. E. \& Paizanos, E. A. (2013). The Effect of Government Expenditure on the Environment: An Empirical Investigation. Ecological Economics,91(3), 48-56.

He, C. F., Pan, F. H., \&Yan, Y. (2012). Is Economic Transition Harmful to China’s Urban Environment? Evidence from Industrial Air Pollution in Chinese Cities. Urban Studies, 49(8) 1767-1790.

Heckman, J. (1979). Sample Selection Bias as A Specification Error. Econometrica, 47(1),153-161.

Heineck, G. \& Anger,S. (2010). The Returns to Cognitive Abilities and Personality Traits in Germany. Labor Economics, 17, 535-546.

Henderson, G. \& Ge, Y. (2005). The Size Distribution of Chinese Cities. Regional Science and Urban Economics, 35, 756-776.

Hofstede, G. (2001). Culture's Consequences, Comparing Values, Behaviors, Institutions and Organizations Across Nations. Thousand Oaks CA: Sage Publications. 
Hsiao, C. (2003). Analysis of Panel Data, Cambridge University Press, Cambridge.

Hsieh, C. T. \& Klenow, P.J. (2009). Misallocation and Manufacturing TFP in China and India. Quarterly Journal of Economics, 124, 1403-1448.

Huber, E., \& Stephens, J. D. (2001). Development and Crisis of the Welfare State. Parties and Policies in Global Markets, University of Chicago Press, Chicago.

Hwang, B. H. \& Kim, S. (2009). It Pays to Have Friends. Social Science Electronic Publishing, 93(1), 138-158.

Jia, R. X. (2013). Pollution for Promotion[J]. International Economic Studies Working Paper.

Jia, R.X., Kudamatsu, M. \& Seim,D. (2015). Political Selection in China: The Complementary Roles of Connections and Performance. Journal of the European Economic Association, 13(4), 631-668.

Jiang, L. L., Lin, C., \& Lin, P. (2014). The Determinants of Pollution Levels: Firm-level Evidence from Chinese Manufacturing. Journal of Comparative Economics, 42(1), 118-142.

Jiang, Z., Wang, Z. \& Li, Z. (2018). The Effect of Mandatory Environmental Regulation on Innovation Performance: Evidence from China. Journal of Cleaner Production, 203, 482-491.

Kato, T. \& Long, C. (2006). Executive Turnover and Firm Performance in China. American Economic Review, 96(2), 363-367.

Kanbur, R. \& Zhang, X. B. (2009). Governing Rapid Growth in China: Equity and Institutions. London: Routledge Press.

Keefe, M. (2019). A Theory of Political Connections and Financial Outcomes. International Review of Economics and Finance, 61, 108-127.

Kim, C. \& Zhang, L. D. (2016). Corporate Political Connections and Tax Aggressiveness.Contemporary Accounting Research, 33(1),78-114.

Kleibergen, F. \& Paap, R. (2006). Generalized Reduced Rank Tests Using the Singular Value Decomposition. Journal of Econometrics, 133(1), 97-126.

Kostka, G. \& Nahm, J. (2017). Central-Local Relations: Recentralization and Environmental Governance in China. The China Quarterly, 231, 567-582. 
Kostka, G. \& Mol, P. J. (2013). Implementation and Participation in China's Local Environmental Politics: Challenges and Innovations. Journal of Environmental Policy \& Planning, 15(1), 3-16.

Konisky, D. M. (2007). Regulatory Competition and Environmental Enforcement, Is There a Race to the Bottom? American Journal of Political Science, 51(4), 853-872.

Kondo, A. \& Shigeoka, H. (2017). The Effectiveness of Demand-Side Government Intervention to Promote Elderly Employment: Evidence from Japan. ILR Review, 70(4), 1008-1036.

Kou, C. W. \& Tsai, W. H. (2014). "Sprinting with Small Steps” Towards Promotion: Solutions for the Age Dilemma in the CCP Cadre Appointment System. The China Journal, 71, 153-171.

Khwaja, A. I., Mian, A. (2005). Do Lenders Favor Politically Connected Firms? Rent Provision in an Emerging Financial Market. The Quarterly Journal of Economics, 120(4), 1371-1411.

Kneller, R. \& Manderson, E. (2012). Environmental Regulations and Innovation Activity in UK Manufacturing Industries. Resource and Energy Economics, 34(2), 211-235.

Lanoie, P., Patry, M., \& Lajeunesse, R. (2008). Environmental Regulation and Productivity Testing the Porter Hpothesis. Journal of Productivity Analysis, 30(2), 121-128.

Lee, S., Yoo, H., \& Nam, M. (2018). Impact of the Clean Air Act on Air Pollution and Infant Health: Evidence from South Korea. Economic Letters, 168, 98-101.

Li, G. P., \& Zhou, H. (2015). Political Connections and Access to IPO Markets in China. China Economic Review, 33, 76-93.

Li, H.\& Zhou, L. A. (2005). Political Turnover and Economic Performance, the Incentive Role of Personnel Control in China. Journal of Public Economics, 89(9), 1743-1762.

List, J. A., Warren, W., \& Millimet, D. L. (2004). Effects of Environmental Regulation on Foreign and Domestic Plant Births, Is There a Home Field Advantage? Journal of Urban Economics, 56(2), 303-326.

Lyon,T. P., \& Maxwell, J. W. (2008). Corporate Social Responsibility and the Environment: A Theoretical Perspective. Review of Environmental Economics and Policy, 2(2), 240-260.

Manderson, E. \& Kneller, R. (2012). Environmental Regulations, Outward FDI and Heterogeneous Firms, 
Are Countries Used as Pollution Havens? Environmental and Resource Economics, 51(3), 317-352.

Marquis, C., Zhang, J. J., \& Zhou, Y. H. (2011). Regulatory Uncertainty and Corporate Responses to Environmental Protection in China. California Management Review, 54(1), 39-63.

Matvos, G. \& Seru, A. (2014). Resource Allocation within Firms and Financial Market Dislocation: Evidence from Diversified Conglomerates. The Review of Financial Studies, 27(4), 1143-1189.

Maung, M., Wilson, C. \&Tang, X. B. (2016). Political Connections and Industrial Pollution: Evidence Based on State Ownership and Environmental Levies in China. Journal of Business Ethics, 138(4), 649-659.

Millimet, D. L. \& Roy, J. (2015). Empirical Tests of the Pollution Haven Hypothesis When Environmental Regulation is Endogenous. Journal of Applied Econometrics, 31(4),652-677.

Mironov, M. \& Zhuravskaya, E. (2016). Corruption in Procurement and the Political Cycle in Tunneling: Evidence from Financial Transactions Data. American Economic Journal: Economic Policy, 8(2), 287-321.

Mobarak, A. \& D. Purbasari, (2006). Corrupt Protection for Sale to Firms, Evidence from Indonesia, Yale University, mimeograph.

Montmartin, B. (2013). Centralized R\&D Subsidy Policy in an NEGG Model, A Welfare Analysis. Louvain Economic Review, 19(1),5-34

Ogawa, H., \& Wildasin, D. E. (2009). Think Locally, Act Locally: Spillovers, Spillbacks, and Efficient Decentralized Policymaking. American Economic Review, 99(4), 1206-1217.

Paler, L. (2013). Keeping the Public Purse: An Experiment in Windfalls, Taxes, and the Incentives to Restrain Government. American Political Science Review, 107(4), 706-725.

Park, A., Rozelle, S., Wong, C. \& Ren, C. Q. Distributional Consequences of Reforming Local Public Finance in China. The China Quarterly, 147, 751-778.

Persson, P. \& Zhuravskaya, E. (2012). Elite Influence as a Substitute for Local Democracy, Evidence from Backgrounds of Chinese Provincial Leaders. Chicago, Social Science Electronic Publishing.

Piotroski. D. O.\& Zhang, T. Y. (2014). Politicians and the IPO Decision, The Impact of Impending 
Political Promotions on IPO Activity in China. Journal of Financial Economics, 111(1), 111-136.

Polsiri, P. \& Jiraporn, P. (2012). Political Connections, Ownership Structure, and Financial Institution Failure. Journal of Multinational Financial Management, 22(1), 39-53.

Qian,Y. \& Weingast, R. (1996). China's Transition to Market, Market-Preserving Federalism, Chinese Style. Journal of Policy Reform, 1(2), 149-185.

Rawski,T. Will Investment Behavior Constrain China's Growth? China Economic Review, 13(4), 361-372.

Richter, P. M., \& Schiersch, A. (2017). CO2 Emission Intensity and Exporting: Evidence from Firm-level Data. European Economic Review, 98, 373-391.

Rodrigue, M., Magnan, M., Charles,C.H. (2013). Is Environmental Governance Substantive or Symbolic? An Empirical Investigation. Journal of Business Ethics, 114(1), 107-129.

vander Kamp, D., Lorentzen, P., \& Mattingly, D. (2017). Racing to the Bottom or to the Top? Decentralization, Revenue Pressures, and Governance Reform in China. World Development, 95, 164-176.

Sanna-Randaccio, F.\& Sestini, R. (2012). The Impact of Unilateral Climate Policy with Endogenous Plant Location and Market Size Asymmetry. Review of International Economics, 20(3),580-99.

Schweizer, D., Walker, T., \& Zhang, A. (2017). Cross-border Acquisitions by Chinese Enterprises: The Benefits and Disadvantages of Political Connections. Journal of Corporate Finance, 28, 1-23.

Sena, V., Duygun, M., Lubrano, G., Marra, M., \& Shaban, M. (2018). Board Independence, Corruption and Innovation. Some Evidence on UK Subsidiaries. Journal of Corporate Finance, 50, 22-43.

Shen, K. R., Jin, G. \& Fang, X. (2017). Does Environmental Regulation Cause Pollution to Transfer Nearby? Economic Research Journal, 5, 44-58 (in Chinese).

Shleifer, A. \& Vishny, R.W. (1994). Politicians and Firms. Quarterly Journal of Economics, 109(4), 995-1025.

Sigman, H. (2007). Decentralization and Environmental Quality, An International Analysis of Water Pollution. NBER Working Papers No.13098.

Styles, C., \& Ambler, T. (2003). The Coexistence of Transactional and Relational Marketing: Insights from 
the Chinese Business Context. Industrial Marketing Management, 32, 633-642.

Su, Z. Q., Xiao Z. P.,Yu, L. (2018). Do Political Connections Enhance or Impede Corporate Innovation? International Review of Economics and Finance, 59, 1-17.

Tahoun, A. \& Lent, L. (2017). The Personal Wealth Interests of Politicians and Government Intervention in the Economy. Review of Finance, 23(1), 37-74.

Tarantino, M. \& Zimmermann, B. (2017). Database Green: Software, Environmentalism and Data Flows in China. The China Quarterly, 229, 205-217.

Tebaldi, E. \& Elmslie, B. (2013). Does Institutional Quality Impact Innovation? Evidence from Cross-country Patent Grant Data. Applied Economics, 45(7), 887-900.

Titl, V. \& Geys, b. (2019). Political Donations and the Allocation of Public Procurement Contracts. European Economic Review, 111(C), 443-458.

Xing, Y. Q. \& Kolstad, C. D. (2002). Do Lax Environmental Regulation Attract Foreign Investment? Environmental and Resource Economics, 21(1), 1-22.

Xu, N., Xu, X., \& Yuan, Q. (2013). Political Connections, Financing Friction, and Corporate Investment, Evidence from Chinese Listed Firms.European Financial Management, 2013, 19(4), 675-702.

Vadlamannati, K. C. (2015). Fighting corruption or elections? The politics of anti-corruption policies in India: A subnational study, Journal of Comparative Economics, 43(4), 1043-1052.

Waldkirch, A. \& Gopinath, M. (2008). Pollution Control and Foreign Direct Investment in Mexico: An Industry-Level Analysis. Environmental and Resource Economics, 41(3), 289-313.

Wang, D. T. \& Chen, W. Y. (2014). Foreign Direct Investment, Institutional Development, and Environmental Externalities, Evidence from China. Journal of Environmental Management, 135(15), 81-94.

Wang, H. \& Jin, Y. H. (2007). Industrial Ownership and Environmental Performance, Evidence from China. Environmental and Resource Economics, 2007, 36(3), 255-273.

Wang, Y. J. \& Sheng, D. (2010). Political Connection and Contract Enforcement Environment. China Economic Quarterly, 11(4), 1193-1218. 
Weingast, B. R. (2009). Second Generation Fiscal Federalism: the Implications of Fiscal Incentives. Journal of Urban Economics, 65(3), 279-293.

Woods, N. D. (2006). Primacy Implementation of Environmental Policy in the U.S. States. Journal of Federalism, 36(2), 259-276.

Wooldridge, J. M. (2010). Econometric Analysis of Cross Section and Panel Data. The MIT Press, Cambridge.

Yang, B. H. (2011). Does Democracy Foster Financial Development? An Empirical Analysis. Economic Letters, 112, (3), 262-265.

Yu, Y. Z., Yang, X. Z., \& Li, K, (2019). Effects of the Terms and Characteristics of Cadres on Environmental Pollution: Evidence from 230 cities in China. Journal of Environmental Management, 232, 179-187.

Yen, D.A. \& Abosa, I. (2016). Localization in China: How Guanxi Moderates Sino-US Business Relationships. Journal of Business Research, 69, 5724-5734.

Zeng, S. H., Jiang, X., Su, B., \& Nan, X. (2018). China's SO2 Shadow Prices and Environmental Technical Efficiency at the Province Level. International Review of Economics \& Finance, 57, 86-102.

Zhang, C. (2017). Political Connections and Corporate Environmental Responsibility: Adopting or Escaping? Energy Economics, 68, 539-547.

Zheng, S. M., Kahn, W., \& Luo, D. (2014). Incentivizing China’s Urban Mayors to Mitigate Pollution Externalities, The Role of the Central Government and Public Environmentalism. Regional Science and Urban Economics,47( 1), 61-71 .

Zheng, W. T., Singh, K. W., \& Chung, C. N. (2017). Ties to Unbind: Political Ties and Firm Sell-Offs During Institutional Transition. Journal of Management, 43(7), 2005-2036.

Zhu, H.J, \& Chung, C.N.(2014). Portfolios of Political Ties and Business Group Strategy in Emerging Economies: Evidence from Taiwan. Administrative Science Quarterly, 59(4), 599-638. 


\begin{tabular}{|c|c|}
\hline Variables & Definition \\
\hline SO2 & Amount of discharged SO2(ton)/sales(10 thousand RMB) \\
\hline Political & $\begin{array}{l}\text { A dummy variable, equals to one if the local official has the same birthplace as } \\
\text { one of the top managers of a listed firm located in the official's jurisdiction and } \\
\text { zero otherwise }\end{array}$ \\
\hline Political_province & $\begin{array}{l}\text { A dummy variable, equals to one if the local official shares the same birthplace as } \\
\text { the top manager at the provincial level and zero otherwise }\end{array}$ \\
\hline Political_school & $\begin{array}{l}\text { A dummy variable, equals to one if the top manager of a listed firm graduated } \\
\text { from the same university as the mayor in whose district the firm is located }\end{array}$ \\
\hline Liability & The ratio of total debts over total assets \\
\hline Profitability & The ratio of net profits over net assets \\
\hline Scale & The natural logarithm of total assets \\
\hline Ownership & $\begin{array}{l}\text { A dummy variable, equals to one if the firm whose ultimate controllers are the } \\
\text { state and zero otherwise }\end{array}$ \\
\hline Population & Populaiton per land area (square kilometer) in each city \\
\hline Pgdp & GDP per capital in each city (10000 RMB) \\
\hline Manufacturing & The ratio of industrial added value in manufacturing to GDP \\
\hline Misallocation & The growth rate of net fixed assets \\
\hline Regulation & $\begin{array}{l}\text { The removal of industrial sulphur dioxide /(the removal of industrial SO2+the } \\
\text { amount of industrial SO2 discharged) in each city }\end{array}$ \\
\hline
\end{tabular}

Appendix B Robustness Checks: Alternative Measures for Political Connections

\begin{tabular}{lcccccc}
\hline \multirow{2}{*}{ Variables } & \multicolumn{3}{c}{ COD } & \multicolumn{3}{c}{ water } \\
& $(1)$ & $(2)$ & $(3)$ & $(4)$ & $(5)$ & $(6)$ \\
\hline \multirow{2}{*}{ Constant } & -1.3333 & -1.4840 & -1.5108 & $-0.3236^{* *}$ & $-0.3429^{* *}$ & $-0.3332^{* *}$ \\
& $(1.1663)$ & $(1.2347)$ & $(1.2363)$ & $(0.1497)$ & $(0.1478)$ & $(0.1484)$
\end{tabular}




\begin{tabular}{|c|c|c|c|c|c|c|}
\hline Political & $\begin{array}{l}0.4329 * \\
(0.2323)\end{array}$ & $\begin{array}{c}1.6722 * * * \\
(0.4862)\end{array}$ & $\begin{array}{c}0.8856 * * \\
(0.3686)\end{array}$ & $\begin{array}{c}0.6036 * * \\
(0.2817)\end{array}$ & $\begin{array}{c}1.4220^{* * *} \\
(0.3701)\end{array}$ & $\begin{array}{c}0.8696 * * \\
(0.4045)\end{array}$ \\
\hline Misallocation & $\begin{array}{c}0.0013^{* * *} \\
(0.0003)\end{array}$ & & & $\begin{array}{c}0.0043^{* * *} \\
(0.0006)\end{array}$ & & \\
\hline Political $\times$ Misallocation & $\begin{array}{l}1.3038 * \\
(0.3133)\end{array}$ & & & $\begin{array}{c}0.0684 \\
(0.0605)\end{array}$ & & \\
\hline Regulation & $\begin{array}{c}-0.2854^{* *} \\
(0.1367)\end{array}$ & & & $\begin{array}{c}-0.2281^{*} \\
(0.1265)\end{array}$ & & \\
\hline Political $\times$ Regulation & $\begin{array}{c}0.5419 * * \\
(0.2352)\end{array}$ & & & $\begin{array}{c}0.4291^{* *} \\
(0.2004)\end{array}$ & & \\
\hline Political×dummy_age1 & & $\begin{array}{c}-0.2196 * * * \\
(0.0729)\end{array}$ & & & $\begin{array}{c}-0.1320 * \\
(0.0789)\end{array}$ & \\
\hline Political×dummy_age2 & & $\begin{array}{c}-0.4841^{*} \\
(0.2655)\end{array}$ & & & $\begin{array}{l}-0.2120 \\
(0.2218)\end{array}$ & \\
\hline Political ×dummy_education & & $\begin{array}{c}-1.4688 * * * \\
(0.3547)\end{array}$ & & & $\begin{array}{c}-0.7011 * * * \\
(0.2568)\end{array}$ & \\
\hline Political $\times$ dummy_tenure & & $\begin{array}{c}-0.5615^{* *} \\
(0.2798)\end{array}$ & & & $\begin{array}{c}-0.4385^{* *} \\
(0.2207)\end{array}$ & \\
\hline Political $\times$ dummy_prom1 & & $\begin{array}{c}-0.6792 * * \\
(0.3319)\end{array}$ & & & $\begin{array}{c}-0.6640 * * \\
(0.3218)\end{array}$ & \\
\hline Political $\times$ dummy_prom2 & & $\begin{array}{l}-0.4499 \\
(0.3064)\end{array}$ & & & $\begin{array}{c}-0.4113^{*} \\
(0.2431)\end{array}$ & \\
\hline Political×dummy_NCCPC & & $\begin{array}{c}-0.2539 \\
(0.2058)\end{array}$ & & & $\begin{array}{l}-0.2386 \\
(0.2110)\end{array}$ & \\
\hline Political×dummy_eastern & & & $\begin{array}{c}-0.6791^{*} \\
(0.3717)\end{array}$ & & & $\begin{array}{c}-0.5932 * \\
(0.3128)\end{array}$ \\
\hline Political ×dummy_central & & & $\begin{array}{c}-0.1233 \\
(0.4136)\end{array}$ & & & $\begin{array}{c}-0.2082 \\
(0.6697)\end{array}$ \\
\hline Political×dummy_municipality & & & $\begin{array}{l}-1.4232 * \\
(0.7287)\end{array}$ & & & $\begin{array}{l}-0.5473 \\
(0.3972)\end{array}$ \\
\hline Political $\times$ dummy_provincial & & & $\begin{array}{c}-0.6057 \\
(0.4126)\end{array}$ & & & $\begin{array}{c}-0.3421^{* *} \\
(0.1623)\end{array}$ \\
\hline Political ×dummy_labor & & & $\begin{array}{c}-0.7545^{* *} \\
(0.3069)\end{array}$ & & & $\begin{array}{c}-0.5721^{*} \\
(0.2974)\end{array}$ \\
\hline Political ×dummy_skill & & & $\begin{array}{c}-0.9082 * * \\
(0.4326)\end{array}$ & & & $\begin{array}{c}-0.6790 * * \\
(0.3256)\end{array}$ \\
\hline Control variables & Yes & Yes & Yes & Yes & Yes & Yes \\
\hline Year dummy & Yes & Yes & Yes & Yes & Yes & Yes \\
\hline City dummy & Yes & Yes & Yes & Yes & Yes & Yes \\
\hline Industry dummy & Yes & Yes & Yes & Yes & Yes & Yes \\
\hline Observations & 14,951 & 14,951 & 14,951 & 14,833 & 14,833 & 14,833 \\
\hline R-squared & 0.1803 & 0.1797 & 0.1795 & 0.1915 & 0.1914 & 0.1915 \\
\hline
\end{tabular}

Note: The dependent variables are listed in the first row. Standard errors clustered at city level are shown in parentheses. $*, * *$ and $* * *$ indicate significance at the $10 \%, 5 \%$ and $1 \%$ levels, respectively.

Appendix C Endogeneity Test on Mechanisms of Political Connections Influencing the Environment

Variables
Dependent variable: SO2

(2) 


\begin{tabular}{|c|c|c|c|}
\hline Constant & $\begin{array}{c}2.5586 * * * \\
(0.6622)\end{array}$ & $\begin{array}{c}2.5594 * * * \\
(0.6624)\end{array}$ & $\begin{array}{c}2.1863 * * * \\
(0.5355)\end{array}$ \\
\hline Political & $\begin{array}{c}0.3489 * * \\
(0.1392)\end{array}$ & & \\
\hline Misallocation & $\begin{array}{c}0.0009 * * * * \\
(0.0004)\end{array}$ & $\begin{array}{c}0.0009 * * * * \\
(0.0004)\end{array}$ & $\begin{array}{c}0.0014 * * \\
(0.0006)\end{array}$ \\
\hline Regulation & $\begin{array}{l}-0.1085 \\
(0.0656)\end{array}$ & $\begin{array}{c}-0.1367^{*} \\
(0.0762)\end{array}$ & $\begin{array}{c}-0.1452^{*} \\
(0.0823)\end{array}$ \\
\hline Political $\times$ Misallocation & $\begin{array}{c}0.6873 * * \\
(0.2858)\end{array}$ & & \\
\hline Political $\times$ Regulation & $\begin{array}{l}0.4648^{*} \\
(0.2403)\end{array}$ & & \\
\hline Match & & $\begin{array}{c}0.2254 * * \\
(0.0902)\end{array}$ & \\
\hline Match $\times$ Misallocation & & $\begin{array}{c}0.6892 * * \\
(0.2858)\end{array}$ & \\
\hline Match $\times$ Regulation & & $\begin{array}{c}0.4178 * * \\
(0.1908)\end{array}$ & \\
\hline Political_IV & & & $\begin{array}{c}0.2689 * * \\
(0.1243)\end{array}$ \\
\hline Political_IV $\times$ Misallocation & & & $\begin{array}{l}0.4746^{*} \\
(0.2690)\end{array}$ \\
\hline Political_IV $\times$ Regulation & & & $\begin{array}{c}0.3101 \\
(0.2048)\end{array}$ \\
\hline$i m r$ & $\begin{array}{l}-0.0299 \\
(0.1669)\end{array}$ & & \\
\hline Control variables & Yes & Yes & Yes \\
\hline Year dummy & Yes & Yes & Yes \\
\hline City dummy & Yes & Yes & Yes \\
\hline Industry dummy & Yes & Yes & Yes \\
\hline Observations & 15,238 & 15,235 & 15,238 \\
\hline R-squared & 0.1259 & 0.1258 & - \\
\hline
\end{tabular}

Note: Column (1) presents the results for the endogeneity test using Heckman's two-stage procedure; Column (2) presents the results for the endogeneity test using PSM procedure; Column (3) presents the results for the endogeneity test using two-stage least square regression. Robust standard errors clustered at city level are shown in parentheses. *, ** and *** indicate significance at the $10 \%, 5 \%$ and $1 \%$ levels, respectively. 